\title{
QUEEN'S
UNIVERSITY
BELFAST
}

\section{Organic phosphorus in the terrestrial environment: A perspective on the state of the art and future priorities.}

George, TS., Giles, CD., Menezes-Blackburn, D., Condron, LM., Gama-Rodrigues, AC., Jaisi, D., Lang, F., Neal, AL., Stutter, MI., Almeida, DS., Bol, R., Cabugao, KG., Celi, L., Cotner, JB., Feng, G., Goll, DS., Hallama, M., Krueger, J., Plassard, C., ... Haygarth, PM. (2017). Organic phosphorus in the terrestrial environment: A perspective on the state of the art and future priorities. Plant and Soil. https://doi.org/10.1007/s11104-017-3391$\mathrm{X}$

Published in:

Plant and Soil

Document Version:

Peer reviewed version

Queen's University Belfast - Research Portal:

Link to publication record in Queen's University Belfast Research Portal

Publisher rights

Copyright 2017 Springer Verlag. This work is made available online in accordance with the publisher's policies. Please refer to any

applicable terms of use of the publisher.

\section{General rights}

Copyright for the publications made accessible via the Queen's University Belfast Research Portal is retained by the author(s) and / or other copyright owners and it is a condition of accessing these publications that users recognise and abide by the legal requirements associated with these rights.

Take down policy

The Research Portal is Queen's institutional repository that provides access to Queen's research output. Every effort has been made to ensure that content in the Research Portal does not infringe any person's rights, or applicable UK laws. If you discover content in the Research Portal that you believe breaches copyright or violates any law, please contact openaccess@qub.ac.uk. 


\section{Plant and Soil}

\section{Organic phosphorus in the terrestrial environment: A perspective on the state of the art and future priorities \\ --Manuscript Draft--}

\begin{tabular}{|c|c|}
\hline Manuscript Number: & PLSO-D-17-00622R1 \\
\hline Full Title: & $\begin{array}{l}\text { Organic phosphorus in the terrestrial environment: A perspective on the state of the art } \\
\text { and future priorities }\end{array}$ \\
\hline Article Type: & Special Issue S69 - OP2016 \\
\hline Keywords: & $\begin{array}{l}\text { cosystems services, Method development, Microbiome, Modelling, Organic } \\
\text { Phosphorus, Stoichiometry. }\end{array}$ \\
\hline Corresponding Author: & $\begin{array}{l}\text { Tim S. George, Ph.D. } \\
\text { James Hutton Institute } \\
\text { Dundee, Scotland UNITED KINGDOM }\end{array}$ \\
\hline \multicolumn{2}{|l|}{$\begin{array}{l}\text { Corresponding Author Secondary } \\
\text { Information: }\end{array}$} \\
\hline Corresponding Author's Institution: & James Hutton Institute \\
\hline \multicolumn{2}{|l|}{$\begin{array}{l}\text { Corresponding Author's Secondary } \\
\text { Institution: }\end{array}$} \\
\hline First Author: & Tim S. George, Ph.D. \\
\hline \multicolumn{2}{|l|}{ First Author Secondary Information: } \\
\hline \multirow[t]{22}{*}{ Order of Authors: } & Tim S. George, Ph.D. \\
\hline & Courtney Giles \\
\hline & Daniel Menezes-Blackburn \\
\hline & Leo Condron \\
\hline & Tony Gama-Rodrigues \\
\hline & Deb Jaisi \\
\hline & Frederike Lang \\
\hline & Andrew Neal \\
\hline & Marc Stutter \\
\hline & Daniel Almeida \\
\hline & Roland Bol \\
\hline & K Carbugao \\
\hline & Luisella Celi \\
\hline & James Cotner \\
\hline & Gu Feng \\
\hline & Daniel Goll \\
\hline & M Hallama \\
\hline & Jaane Krueger \\
\hline & Claude Plassard \\
\hline & Anna Rosling \\
\hline & Tegan Darch \\
\hline & Tandra Fraser \\
\hline
\end{tabular}




\section{Reiner Giesler}

Alan Richardson

Federica Tamburini

Charles Shand

David Lumsdon

Hao Zhang

Martin Blackwell

Catherine Wearing

Malika Mezeli

Åsgeir Almås

Yuki Audette

Isabelle Bertrand

E Beyhaut

Gustavo Boitt

N Bradshaw

Charles Brearley

Tom Bruulsema

Philippe Ciais

Vincenza Cozzolino

P Cuevas

Mariluz Mora

A de Menezes

Rosalind Dodd

Kari Dunfield

C Engl

J Frazão

Gina Garland

Jose González Jiménez

Jessica Graca

Stephen Granger

Anthony Harrison

Christine Heuck

E Hou

Penny Johnes

Klaus Kaiser

H Kjær

Erwin Klumpp

A Lamb

Katrina Macintosh

E Mackay

Powered by Editorial Mardonge,McGrath 


\begin{tabular}{|c|c|c|}
\hline \multicolumn{3}{|c|}{ Catherine Mclntyre } \\
\hline & \multicolumn{2}{|l|}{ Timothy McLaren } \\
\hline & \multicolumn{2}{|l|}{ Eva Mészáros } \\
\hline & \multicolumn{2}{|l|}{ Anna Missong } \\
\hline & \multicolumn{2}{|l|}{ M Mooshammer } \\
\hline & \multicolumn{2}{|l|}{ C Negrón } \\
\hline & \multicolumn{2}{|l|}{ L Nelson } \\
\hline & \multicolumn{2}{|l|}{ Verena Pfahler } \\
\hline & \multicolumn{2}{|l|}{ P Poblete-Grant } \\
\hline & \multicolumn{2}{|l|}{ Matt Randall } \\
\hline & \multicolumn{2}{|l|}{ Alex Segeul } \\
\hline & \multicolumn{2}{|l|}{ Kritarth Seth } \\
\hline & \multicolumn{2}{|l|}{ Andrew Smith } \\
\hline & \multicolumn{2}{|l|}{ Mark Smits } \\
\hline & \multicolumn{2}{|l|}{ J Sobarzo } \\
\hline & \multicolumn{2}{|l|}{ Marie Spohn } \\
\hline & \multicolumn{2}{|l|}{ K Tawaraya } \\
\hline & \multicolumn{2}{|l|}{ Mark Tibbett } \\
\hline & \multicolumn{2}{|l|}{ P Voroney } \\
\hline & \multicolumn{2}{|l|}{ Hakan Wallander } \\
\hline & \multicolumn{2}{|l|}{ Lim Wang } \\
\hline & \multicolumn{2}{|l|}{ Jun Wasaki } \\
\hline & \multicolumn{2}{|l|}{ Philip Haygarth } \\
\hline \multicolumn{3}{|c|}{ Order of Authors Secondary Information: } \\
\hline \multirow[t]{2}{*}{ Funding Information: } & $\begin{array}{l}\text { Biotechnology and Biological Sciences } \\
\text { Research Council } \\
\text { (BB/K018167/1) }\end{array}$ & $\begin{array}{l}\text { Dr. Tim S. George } \\
\text { Dr Courtney Giles } \\
\text { Dr Daniel Menezes-Blackburn } \\
\text { Dr Marc Stutter } \\
\text { Dr Tegan Darch } \\
\text { Dr Charles Shand } \\
\text { Dr David Lumsdon } \\
\text { Dr Hao Zhang } \\
\text { Dr Martin Blackwell } \\
\text { Ms Catherine Wearing } \\
\text { Prof Philip Haygarth }\end{array}$ \\
\hline & $\begin{array}{l}\text { Biotechnology and Biological Sciences } \\
\text { Research Council } \\
\text { (BB/L025671/2) }\end{array}$ & $\begin{array}{l}\text { Dr Tandra Fraser } \\
\text { Prof Mark Tibbett }\end{array}$ \\
\hline Abstract: & \multicolumn{2}{|c|}{$\begin{array}{l}\text { Background: The dynamics of phosphorus }(\mathrm{P}) \text { in the environment is important for } \\
\text { regulating nutrient cycles in natural and managed ecosystems and an integral part in } \\
\text { assessing biological resilience against environmental change. Organic } \mathrm{P}(\mathrm{Po}) \\
\text { compounds play key roles in biological and ecosystems function in the terrestrial } \\
\text { environment, being critical to cell function, growth and reproduction. } \\
\text { Scope: We asked a group of experts to consider the global issues associated with Po } \\
\text { in the terrestrial environment, methodological strengths and weaknesses, benefits to } \\
\text { be gained from understanding the Po cycle, and to set priorities for Po research. } \\
\text { Conclusions: We identified seven key opportunities for Po research including: the need }\end{array}$} \\
\hline
\end{tabular}


for integrated, quality controlled and functionally based methodologies; assessment of stoichiometry with other elements in organic matter; understanding the dynamics of Po in natural and managed systems; the role of microorganisms in controlling Po cycles; the implications of nanoparticles in the environment and the need for better modelling and communication of the research. Each priority is discussed and a statement of intent for the Po research community is made that highlights there are key contributions to be made toward understanding biogeochemical cycles, dynamics and function of natural ecosystems and the management of agricultural systems

Response to Reviewers:
Rebuttal Major Revisions requested PLSO-D-17-00622

\section{Editor Comments}

There are additional comments in the box for the Editor, but I will leave those out except for one: "I do not like the multi-author list as they will not have all contributed to this paper. Conference attendees could be listed in an Appendix." Please consider that option, which makes sense, but I will leave it to you to decide how to proceed.

See response to comments below. We would like to keep the authorship as it is for this submission.

\section{Reviewer \#1}

This manuscript is difficult to review for a number of reasons. As an opinion piece it represents the opinions, presumably, of the first 20 or so authors, and the 'assent' of the remaining 70 -odd (where alphabetical order begins). So, no new science is presented in the manuscript. And as an opinion piece, the review of the various identified areas and priorities is incomplete and not comprehensive. At least a third of each section recapitulates basic facts and then cites some interesting observations within each of those areas, usually by authors who are listed in the manuscript. As a reviewer, there is actually little to review.

The written synthesis of the content is the work of the 20 or so of the first authors, but all authors contributed to the production of the information that was synthesised and therefore warrant inclusion in the author list. We have decided to keep the author list as it is, as this authorship was offered to participants in the data collection part of the process at the start and I would not want to go back on that agreement. There is no new science presented as it is a synthesis of expert opinion and any perceived blandness in the observations is down to trying to achieve a consensus statement between $80+$ authors with varying backgrounds and opinions. We are unable to change the content as we went through a rational process to gather the information and this is what we got. So the piece should either be considered a worthwhile contribution as it is or not.

I disagree with a number of the areas listed here, yet, in reality it is irrelevant. For example, a) a key area of organic $P$ research focus should be on identifying the large, non-phytate, fraction present, presumably, in the broad peak of NMR studies (Jarosch et al. 2015); first identified by the chromatography work of Cosgrove half a century ago. In reality, we don't know what half the organic $P$ in soil actually is, yet that doesn't seem to have been identified as a priority? b) Furthermore, there was acknowledged (in the paper) disagreement at the conference about the value of standardised methodologies and worldwide reference samples, with some arguing that fixing the standards will advance organic $\mathrm{P}$ characterisation and others arguing against that position. The consensus is oddly described, as many of the authors have published more advanced deconvolution techniques that are moving the science forward and allowing the characterisation and correction of methodological over-allocation of different Po classes. This fluidity may not have occurred if standard methods were fixed according to old methods. c) A comprehensive review of stoichometric ratios of $\mathrm{C}:$ Po many years ago at a conference I attended made it very clear that the range is wide, unlikely to be associated with specific compounds that are identifiable, and is perhaps easily confused by metal- $P$ linkages with $\mathrm{P}$ in organic attachments.

Suggesting great leaps can be made in this area struck me as optimistic. d) The land management section describes reasonably clearly that withdrawing $P$ fertiliser results in drawdown of inorganic P sources (and some accumulation of Po)(Ins 255-266), yet 
the odd consensus question that immediately follows asks how long turnover of organic $\mathrm{P}$ can sustain crop yields (In 261-262)? None of these are errors in science per se (though the last one is illogical) and are merely my opinions on their opinions and are not grounds for rejecting a manuscript.

As above, these opinions were formed out of the opinions of the experts contributing to the information. All these areas were debated and many of the opinions were stated and moderated to achieve the consensus that exists in the text. I have made some additions to the text to highlight some of these alternate opinions, but am unwilling to go too far against the consensus to represent a single opinion (as you point out).

Is it new and innovative? No. Is it interesting to organic P scientists? I did not find so. Did I learn new research directions that will revolutionise organic P science? Not really.

It's a shame that you felt so underwhelmed by the manuscript. I would argue that there is merit in making a statement from a globally represented community on the consensus of this particular area of research, but if this did not come across then I am disappointed.

However, my opinions are merely some amongst many and are not grounds for rejecting a manuscript. I believe it is a question for the editor. Does Plant and Soil want to provide a platform for a semi-review opinion piece associated with a Special Issue? Many publications have done it in the past, and the advertisement of various organic $\mathrm{P}$ groupings under the guise of a communication 'opportunity' emphasises the aims of the piece.

I am also happy to leave it up the editor whether this is an appropriate paper for publication or not.

Reviewer \#2: Review of the MS: PLSO-D-17-00622 entitled "Organic phosphorus in the terrestrial environment: A perspective on the state of the art and future priorities" and authored by George and others

This paper is a hybrid between a review on organic $\mathrm{P}$ in terrestrial systems and a report on the opinion of the participants of the last organic $\mathrm{P}$ meeting on priorities for future organic $P$ research.

Sometime ago, Turner et al (2005) (chap 17 Synthesis and recommendations for future research; in Organic phosphorus in the environment, $\mathrm{CABI}$ ), published a paper presenting the opinion of participants to an organic $\mathrm{P}$ conference on the future and relevance of organic $\mathrm{P}$ research. Whereas, many new research results have been published since then, I could not see clear differences between these two papers with respect to the future and relevance of organic $P$ research. I would therefore advise the authors of this manuscript first to refer to this previous paper and then to show how the point of view of the Po community on the future of Po research has evolved.

I have done as suggested and an additional paragraph has been added to the manuscript to summarise how things have changed in the last decade and reference added, as follows.

"The key opportunities to improve the effectiveness of Po research identified here are similar to those highlighted in Turner et al. (2005), although it is clear that some progress has been made since that set of recommendations were made. However, the similarities and consistency between the outcome of these two studies suggests we still have some progress to make. A number of new priority areas were identified here that were not identified in Turner et al. (2005), including the need for greater understanding of the metagenomics and functional microbial genes involved in organic $\mathrm{P}$ turnover, greater understanding of the impact of nanoparticles in the environment on organic $\mathrm{P}$ turnover and the need to integrate the system more effectively in the form of models. It is clear that Po research field is evolving, but some of the issues of a decade ago still persist."

LL 65-66 The summary starts with this sentence: "The dynamics of phosphorus $(P)$ in the environment is critical for ... assessing biological resilience against environmental 
change." This sounds like a definitive statement. However, I do not think that this paper shows that. Either it is shown or it should be deleted.

This part of the summary is the background, so it is meant to reflect the prior art rather than the content of the paper and we consider that the literature does back up this statement. However, we have toned down the language so it is less of a definitive statement.

L 69 Sorry but I do not understand the scope: what are the "benefits of Po in organisms and the environment"? Why and which benefits?

Scope reworded to give clarity on what the scope of the study was.

L 106 Plants and other organisms drive the conversion of $\mathrm{Pi}$ to $\mathrm{Po}$.

Changed as suggested

$\mathrm{L} 110$ Is the simplest definition the one that holds for this paper?

Yes, we think so, but modified slightly as highlighted below.

$\mathrm{L} 111$ Why carbon-hydrogen bonds? Why not organic $\mathrm{P}$ is $\mathrm{P}$ covalently bound to an organic radical

These definitions reflect the methodological approaches used to measure Po by many of the researchers consulted in this exercise and often where it is possible to define a particular form of Po this is done by liquid state NMR or chromatography, which tend to identify the type of bonds highlighted. I would suggest that we are talking about specific organic moieties of phosphate and the other types of "organic P" would be defined as $\mathrm{P}$ associated with organic matter. The text has been modified to reflect this.

Fig1 Inositol phosphates have not always a "low soil lability" (whatever this means), in some cases inositol phosphates have been shown to be rapidly mineralized or to be absent from soil organic matter.

This figure is illustrative and taken from another publication, so we do not wish to modify it. Soil lability is a relative term, so while we agree that under certain circumstances inositol $\mathrm{P}$ is labile and turns over rapidly, in general in many soils it tends to turnover relatively little and accumulates when compared to compounds with greater "soil lability" such as diesters. So as a relative term we think this is adequate.

L 123 This statement "At present there is no evidence for direct uptake of dissolved Po compounds by biology" is wrong, as phosphonate uptake by bacteria has been observed in marine systems (Dyhrman et al 2006).

Information and reference added to the text.

L 126 Why "potential"

Removed

L 138 Explain how the consensus was reached?

Text added to clarify how the consensus was reached.

$L 154$ Add references in which these discussion and debate are shown at the end of the sentence.

References added.

L 154 Should not you add a comma after "Despite this"?

Added 
$L 161$ Add a supporting reference at the end of the sentence.

Reference added.

L 166 I like the idea of a standard manure, but is it realistic?

Text added to allude to the difficulty of this.

L 170-2 How does the commercial supply relates to the understanding of a behavior of a given Po compound.

Text added to clarify this

L $172-5$ Is this last sentence really useful?

We have a priority statement at the end of each section and we would like to keep this one.

L 209 This statement is correct and this topic has been discussed in:

Frossard E, N Buchmann, EK Bünemann, DI Kiba, F Lompo, A Oberson, F Tamburini, OYA Traoré 2016 Soil properties and not inputs control carbon : nitrogen : phosphorus ratios in cropped soils in the long term, SOIL 2: 83-99 www.soil-journal.net/2/83/2016/ doi:10.5194/soil-2-83-2016 L 216-221: These statements need to be supported by appropriate references.

Reference added

L 229-230 I do not understand the beginning of the sentence "Key opportunities exist for and it is imperative to ..."

Sentence changed to make sense

L 230 I am surprised to see that nowhere the authors explicitly mention the needs to quantify fluxes of $\mathrm{P}$ (or Po) between compartments.

This is dealt with in Section $4 \mathrm{~b}$, later in the text

L 250 Annaheim et al did not work on organic farming.

Text added to clarify this point.

L 252 What is a greater abundance? Thanks for quantifying it. L 252-3 What does "a greater abundance of Po, especially diester $\mathrm{P}$... maintained acceptable yields" mean? How can diester $P$ maintain yield? What is acceptable?

Information added and text changed accordingly.

L 253 I do not see the usefulness of the sentence starting with "the utilization of ..."

Removed

$L 261$ You need to integrate the input/output $P$ balance in your key question, otherwise it does not make sense.

Added accordingly

L 265 Which are the traditional cultivation practices in which Po plays a more dominant role? Do you have data and a reference for that?

Sentence removed.

L 302 Are you sure that this correlation is always working? I could not see it e.g. in Ragot's work. I rather think that the Canadian case is a nice but specific case. 
Information added.

$\mathrm{L} 303$ This statement is not correct, there is also info on phoX in soils.

Ragot SA, MA Kertesz, E Mészáros, E Frossard, EK Bünemann 2017 Soil phoD and phoX alkaline phosphatase gene diversity responds to multiple environmental factors, FEMS Microbiology Ecology 93, fiw212 doi: 10.1093/femsec/fiw212

Information added.

L 342 Radioactivity is not correctly spelled out.

Corrected

L 378 Is it possible to do a complete LCA on Po? I do not think that it makes a lot of sense as $\mathrm{Po}$ can not be seen independently of $\mathrm{Pi}$.

Changed accordingly.

I did not study with attention the reference list, but I could see points to be addressed. Sometimes the names of journals are abbreviated sometimes not.

I am not sure whether the work of Borda et al (2011) is related to Po.

The reference to Cade Menun et al (2005) is not correct.

The reference to Celi and Barberis (2005) is to be completed with scientific and publishing editors...

Checked and changed accordingly.

Reviewer \#3: The series of organic phosphorus conferences have been a very welcome forum for developing common understanding of the forms and dynamics of organic $\mathrm{P}$ cycling in terrestrial and to a lesser extent aquatic ecosystems, and the traditional and emerging methodologies to measure this important $\mathrm{P}$ fraction. This paper attempts to summarise the most recent conference re the current state of Po research with respect to the terrestrial environment and where future work is needed. This is an important and difficult task given the methodology challenges and complexity of Po cycling routes, and I think the authors have produced an excellent summary. They have adequately highlighted how Po understanding is key to developing solutions to global issues, and the key research areas where progress is needed. I have no major issues with the areas identified but think that more emphasis is needed on some key recent developments regarding the sustainability of $\mathrm{P}$ management. I also wondered why the focus was just on the terrestrial environment rather than also covering the aquatic environment since managing Po on land requires an appreciation of its fate and impact in water!

We would like to thank the reviewer for their positive appraisal of the paper and what we were trying to achieve with the manuscript. As highlighted above, we had a rationale for collecting the information and through this process we were unsuccessful in collecting consensus opinions on the aquatic environment. This probably reflects the background of the participants and only a few came from an aquatic background, so it is under represented. The title states that this is specifically assessing the terrestrial environment because of this. I would be loathed to add in some superficial analysis of the aquatic environment at this stage, so suggest the text remains focused on the terrestrial environment.

Firstly the introduction talks about the importance of Po for biota and then rather abruptly at line 129 talks about the aims of the paper. I think the authors could make a linking paragraph here by making the point that considerable progress in understanding Po in ecosystems has been made in recent years and outline what these key developments have been (NMR, rhizosphere etc). Why are Po research challenges particularly timely now?

Short paragraph added for this purpose. 
The recent focus on the need to manage $\mathrm{P}$ more sustainably in society (for environmental, economic and resource protection reasons) has two major justifications for organic Po research which I do not feel are really brought out in the paper. Some aspects are touched upon in the paper but it could be more forcefully presented. Certainly the conclusions could usefully include these arguments to justify a greater research effort on Po. The first is that we must reduce reliance on traditional inorganic $\mathrm{P}$ fertilisers (ie primary $\mathrm{P}$ ) in the future, and strategies towards reducing reliance on soil inorganic $\mathrm{P}$ fertility (ie lowering critical soil $\mathrm{P}$ ) will increase the relevance of soil organic $\mathrm{P}$ for providing available $\mathrm{P}$ for general ES provision. Secondly, the need to develop a circular $\mathrm{P}$ economy and close the $\mathrm{P}$ cycle will likely lead to an increase in the amounts of organic $\mathrm{P}$ bioresources (ie secondary $\mathrm{P}$ ) that are recycled to land in the future and this increased recycling of $\mathrm{Po}$ is potentially important for shifting the Po/Pi balance in the soil and the functionality of the soil microbial community and $\mathrm{C}$ sequestration.

This has now been emphasised in the conclusion text.

More specific comments:

Line 70 - terrestrial environment is the scope here.

Information added.

Keywords = organic phosphorus needs to be included!

Added.

Line 117 - relative to inorganic $P$ forms Line 121 - why is phytase not mentioned here?

Added.

Line 123 - Is it worth mentioning that organic $\mathrm{N}$ is taken up by plants directly?

Added.

Line 140 - ecosystem resilience could be included in the list of global issues

Research priority 1 - the term 'real'-time' monitoring is not mentioned specifically but its hinted at in terms of linking forms to processes. Is this a possibility in the future or is the methodology too complex? Its there for Pi of course.

This wasn't seen as a realistic possibility by the consensus so was not included here.

Research priority 2 - para starting line 178 - why is there no mention of the CNP stoichiometry of crop plants here as they are competing for nutrient resources with the microbes?

Information added.

Line 208 - 'optimal stoichiometry' - its not clear here whether your just talking Po or total P?

Information added.

Research priority 3 - is it likely that Po will only really contribute to available $\mathrm{P}$ supply to crops when $\mathrm{Pi}$ has been depleted? Some clarification on current thoughts would be helpful here - eg line 259.

Clarification added.

The first research opportunity in Table 1 is not covered in the text?

This was a priority identified by all groups in the process, but we did not highlight it in 
the text as the implications of this are more to do with the societal research model and beyond our scope here.

Table 1 highlights carbon sequestration as a global issue but the trade off between utilization of $\mathrm{Po}$ and $\mathrm{C}$ is not really discussed?

This is alluded to in section 3 when we discuss the use of organic $P$ as a nutrient source and is implicit in the stoichiometry discussion.

What about the role of Po in the remediation of contaminated soils - heavy metals inputs etc.

This did not come up in any of the discussion groups and therefore did not make it into the consensus statements.

Overall this is a very welcome contribution from the $\mathrm{P}$ research community and I fully support publication. I have issues with including so many authors but that must be a decision for the editor!

Thank you again for the positive review of the paper and the authorship issue is discussed above in response to reviewer \#1 and editor comments. 
Dr T.S.George

The James Hutton Institute

Invergowrie

Dundee

DD2 5DA

UK

03/08/2017

Prof Hans Lambers

Editor-in-Chief Plant and Soil

The University of Western Australia,

Crawley,

Australia

Dear Hans,

Please find enclosed the revised version of the manuscript "Organic Phosphorus in the Terrestrial Environment: A perspective on the state of the art and future priorities" by T.S. George et al. that is resubmitted to be considered for publication in Plant and Soil in the special issue from the OP2016 meeting being edited by Phil Haygarth et al.

We have taken into consideration all the comments raised and as such have made a number of changes to the paper (as outlined in the rebuttal). In particular, we have altered added some paragraphs for clarity and to make reference to other similar studies of the past. We have clarified some of our terminology and justified and clarified some of the statements made. We have made arguments to keep some of the content and to maintain the large number of authors. We would like to thank you and the reviewers for bringing these points to our attention as we think it has made an important difference to the quality of this paper.

Given the improvements made to the clarity of the manuscript and our defence of aspects that have not been changed, we believe this manuscript offers an important contribution to prioritising future research on organic $\mathrm{P}$. We hope then that you will now find the paper to be appropriate for publication in Plant and Soil. We look forward to your reply.

Yours sincerely

Timothy S George 
Rebuttal Major Revisions requested PLSO-D-17-00622

Editor Comments

There are additional comments in the box for the Editor, but I will leave those out except for one: "I do not like the multi-author list as they will not have all contributed to this paper. Conference attendees could be listed in an Appendix." Please consider that option, which makes sense, but I will leave it to you to decide how to proceed.

See response to comments below. We would like to keep the authorship as it is for this submission.

Reviewer \#1

This manuscript is difficult to review for a number of reasons. As an opinion piece it represents the opinions, presumably, of the first 20 or so authors, and the 'assent' of the remaining 70 -odd (where alphabetical order begins). So, no new science is presented in the manuscript. And as an opinion piece, the review of the various identified areas and priorities is incomplete and not comprehensive. At least a third of each section recapitulates basic facts and then cites some interesting observations within each of those areas, usually by authors who are listed in the manuscript. As a reviewer, there is actually little to review.

The written synthesis of the content is the work of the $\mathbf{2 0}$ or so of the first authors, but all authors contributed to the production of the information that was synthesised and therefore warrant inclusion in the author list. We have decided to keep the author list as it is, as this authorship was offered to participants in the data collection part of the process at the start and I would not want to go back on that agreement. There is no new science presented as it is a synthesis of expert opinion and any perceived blandness in the observations is down to trying to achieve a consensus statement between $80+$ authors with varying backgrounds and opinions. We are unable to change the content as we went through a rational process to gather the information and this is what we got. So the piece should either be considered a worthwhile contribution as it is or not.

I disagree with a number of the areas listed here, yet, in reality it is irrelevant. For example, a) a key area of organic $P$ research focus should be on identifying the large, non-phytate, fraction present, presumably, in the broad peak of NMR studies (Jarosch et al. 2015); first identified by the chromatography work of Cosgrove half a century ago. In reality, we don't know what half the organic $P$ in soil actually is, yet that doesn't seem to have been identified as a priority? $b$ ) Furthermore, there was acknowledged (in the paper) disagreement at the conference about the value of standardised methodologies and worldwide reference samples, with some arguing that fixing the standards will advance organic $P$ characterisation and others arguing against that position. The consensus is oddly described, as many of the authors have published more advanced deconvolution techniques that are moving the science forward and allowing the characterisation and correction of methodological over-allocation of different Po classes. This fluidity may not have occurred if standard methods were fixed according to old methods. c) A comprehensive review of stoichometric ratios of C:Po many years ago at a conference I attended made it very clear that the range is wide, unlikely to be associated with specific compounds that are identifiable, and is perhaps easily confused by metal-P linkages with $P$ in organic attachments. Suggesting great leaps can be made in this area struck me as optimistic. d) The land management section describes reasonably clearly that withdrawing P fertiliser results in drawdown of inorganic P sources (and some accumulation of Po)(Ins 255-266), yet the odd consensus question that immediately follows asks how long turnover of organic P can sustain crop yields (In 261-262)? None of these are errors in 
science per se (though the last one is illogical) and are merely my opinions on their opinions and are not grounds for rejecting a manuscript.

As above, these opinions were formed out of the opinions of the experts contributing to the information. All these areas were debated and many of the opinions were stated and moderated to achieve the consensus that exists in the text. I have made some additions to the text to highlight some of these alternate opinions, but am unwilling to go too far against the consensus to represent a single opinion (as you point out).

Is it new and innovative? No. Is it interesting to organic P scientists? I did not find so. Did I learn new research directions that will revolutionise organic $P$ science? Not really.

It's a shame that you felt so underwhelmed by the manuscript. I would argue that there is merit in making a statement from a globally represented community on the consensus of this particular area of research, but if this did not come across then I am disappointed.

However, my opinions are merely some amongst many and are not grounds for rejecting a manuscript. I believe it is a question for the editor. Does Plant and Soil want to provide a platform for a semi-review opinion piece associated with a Special Issue? Many publications have done it in the past, and the advertisement of various organic $P$ groupings under the guise of a communication 'opportunity' emphasises the aims of the piece.

I am also happy to leave it up the editor whether this is an appropriate paper for publication or not.

Reviewer \#2: Review of the MS: PLSO-D-17-00622 entitled "Organic phosphorus in the terrestrial environment: A perspective on the state of the art and future priorities" and authored by George and others

This paper is a hybrid between a review on organic $P$ in terrestrial systems and a report on the opinion of the participants of the last organic $P$ meeting on priorities for future organic $P$ research. Sometime ago, Turner et al (2005) (chap 17 Synthesis and recommendations for future research; in Organic phosphorus in the environment, $\mathrm{CABI}$ ), published a paper presenting the opinion of participants to an organic $P$ conference on the future and relevance of organic $P$ research. Whereas, many new research results have been published since then, I could not see clear differences between these two papers with respect to the future and relevance of organic $P$ research. I would therefore advise the authors of this manuscript first to refer to this previous paper and then to show how the point of view of the Po community on the future of Po research has evolved.

I have done as suggested and an additional paragraph has been added to the manuscript to summarise how things have changed in the last decade and reference added, as follows. "The key opportunities to improve the effectiveness of Po research identified here are similar to those highlighted in Turner et al. (2005), although it is clear that some progress has been made since that set of recommendations were made. However, the similarities and consistency between the outcome of these two studies suggests we still have some progress to make. A number of new priority areas were identified here that were not identified in Turner et al. (2005), including the need for greater understanding of the metagenomics and functional microbial genes involved in organic $P$ turnover, greater understanding of the impact of nanoparticles in the environment on organic $P$ turnover and the need to integrate the system more effectively in the form of models. It is clear that Po research field is evolving, but some of the issues of a decade ago still persist." 
LL 65-66 The summary starts with this sentence: "The dynamics of phosphorus $(P)$ in the environment is critical for ... assessing biological resilience against environmental change." This sounds like a definitive statement. However, I do not think that this paper shows that. Either it is shown or it should be deleted.

This part of the summary is the background, so it is meant to reflect the prior art rather than the content of the paper and we consider that the literature does back up this statement. However, we have toned down the language so it is less of a definitive statement.

L 69 Sorry but I do not understand the scope: what are the "benefits of Po in organisms and the environment"? Why and which benefits?

Scope reworded to give clarity on what the scope of the study was.

L 106 Plants and other organisms drive the conversion of Pi to Po.

Changed as suggested

$\mathrm{L} 110$ Is the simplest definition the one that holds for this paper?

Yes, we think so, but modified slightly as highlighted below.

L 111 Why carbon-hydrogen bonds? Why not organic $\mathrm{P}$ is $\mathrm{P}$ covalently bound to an organic radical

These definitions reflect the methodological approaches used to measure $P_{o}$ by many of the researchers consulted in this exercise and often where it is possible to define a particular form of $P_{0}$ this is done by liquid state NMR or chromatography, which tend to identify the type of bonds highlighted. I would suggest that we are talking about specific organic moieties of phosphate and the other types of "organic P" would be defined as P associated with organic matter. The text has been modified to reflect this.

Fig1 Inositol phosphates have not always a "low soil lability" (whatever this means), in some cases inositol phosphates have been shown to be rapidly mineralized or to be absent from soil organic matter.

This figure is illustrative and taken from another publication, so we do not wish to modify it. Soil lability is a relative term, so while we agree that under certain circumstances inositol $P$ is labile and turns over rapidly, in general in many soils it tends to turnover relatively little and accumulates when compared to compounds with greater "soil lability" such as diesters. So as a relative term we think this is adequate.

L 123 This statement "At present there is no evidence for direct uptake of dissolved Po compounds by biology" is wrong, as phosphonate uptake by bacteria has been observed in marine systems (Dyhrman et al 2006).

Information and reference added to the text.

L 126 Why "potential" 


\section{Removed}

L 138 Explain how the consensus was reached?

Text added to clarify how the consensus was reached.

L 154 Add references in which these discussion and debate are shown at the end of the sentence.

References added.

L 154 Should not you add a comma after "Despite this"?

Added

L 161 Add a supporting reference at the end of the sentence.

Reference added.

L 166 I like the idea of a standard manure, but is it realistic?

Text added to allude to the difficulty of this.

L 170-2 How does the commercial supply relates to the understanding of a behavior of a given Po compound.

\section{Text added to clarify this}

L 172-5 Is this last sentence really useful?

We have a priority statement at the end of each section and we would like to keep this one.

L 209 This statement is correct and this topic has been discussed in:

Frossard E, N Buchmann, EK Bünemann, DI Kiba, F Lompo, A Oberson, F Tamburini, OYA Traoré 2016 Soil properties and not inputs control carbon : nitrogen : phosphorus ratios in cropped soils in the long term, SOIL 2: 83-99 www.soil-journal.net/2/83/2016/ doi:10.5194/soil-2-83-2016 L 216-221: These statements need to be supported by appropriate references.

\section{Reference added}

L 229-230 I do not understand the beginning of the sentence "Key opportunities exist for and it is imperative to ..."

\section{Sentence changed to make sense}

$L 230$ I am surprised to see that nowhere the authors explicitly mention the needs to quantify fluxes of $\mathrm{P}$ (or Po) between compartments.

This is dealt with in Section $4 b$, later in the text

L 250 Annaheim et al did not work on organic farming. 


\section{Text added to clarify this point.}

L 252 What is a greater abundance? Thanks for quantifying it. L 252-3 What does "a greater abundance of Po, especially diester P ... maintained acceptable yields" mean? How can diester P maintain yield? What is acceptable?

Information added and text changed accordingly.

L 253 I do not see the usefulness of the sentence starting with "the utilization of ..."

\section{Removed}

$L 261$ You need to integrate the input/output $P$ balance in your key question, otherwise it does not make sense.

\section{Added accordingly}

L 265 Which are the traditional cultivation practices in which Po plays a more dominant role? Do you have data and a reference for that?

\section{Sentence removed.}

L 302 Are you sure that this correlation is always working? I could not see it e.g. in Ragot's work. I rather think that the Canadian case is a nice but specific case.

\section{Information added.}

$L 303$ This statement is not correct, there is also info on phoX in soils. Ragot SA, MA Kertesz, E Mészáros, E Frossard, EK Bünemann 2017 Soil phoD and phoX alkaline phosphatase gene diversity responds to multiple environmental factors, FEMS Microbiology Ecology 93, fiw212 doi: 10.1093/femsec/fiw212

\section{Information added.}

L 342 Radioactivity is not correctly spelled out.

\section{Corrected}

L 378 Is it possible to do a complete LCA on Po? I do not think that it makes a lot of sense as Po can not be seen independently of Pi.

\section{Changed accordingly.}

I did not study with attention the reference list, but I could see points to be addressed.

Sometimes the names of journals are abbreviated sometimes not.

I am not sure whether the work of Borda et al (2011) is related to Po.

The reference to Cade Menun et al (2005) is not correct.

The reference to Celi and Barberis (2005) is to be completed with scientific and publishing editors...

\section{Checked and changed accordingly.}


Reviewer \#3: The series of organic phosphorus conferences have been a very welcome forum for developing common understanding of the forms and dynamics of organic $\mathrm{P}$ cycling in terrestrial and to a lesser extent aquatic ecosystems, and the traditional and emerging methodologies to measure this important $P$ fraction. This paper attempts to summarise the most recent conference re the current state of Po research with respect to the terrestrial environment and where future work is needed. This is an important and difficult task given the methodology challenges and complexity of Po cycling routes, and I think the authors have produced an excellent summary. They have adequately highlighted how Po understanding is key to developing solutions to global issues, and the key research areas where progress is needed. I have no major issues with the areas identified but think that more emphasis is needed on some key recent developments regarding the sustainability of P management. I also wondered why the focus was just on the terrestrial environment rather than also covering the aquatic environment since managing Po on land requires an appreciation of its fate and impact in water!

We would like to thank the reviewer for their positive appraisal of the paper and what we were trying to achieve with the manuscript. As highlighted above, we had a rationale for collecting the information and through this process we were unsuccessful in collecting consensus opinions on the aquatic environment. This probably reflects the background of the participants and only a few came from an aquatic background, so it is under represented. The title states that this is specifically assessing the terrestrial environment because of this. I would be loathed to add in some superficial analysis of the aquatic environment at this stage, so suggest the text remains focused on the terrestrial environment.

Firstly the introduction talks about the importance of Po for biota and then rather abruptly at line 129 talks about the aims of the paper. I think the authors could make a linking paragraph here by making the point that considerable progress in understanding Po in ecosystems has been made in recent years and outline what these key developments have been (NMR, rhizosphere etc). Why are Po research challenges particularly timely now?

Short paragraph added for this purpose.

The recent focus on the need to manage $P$ more sustainably in society (for environmental, economic and resource protection reasons) has two major justifications for organic Po research which I do not feel are really brought out in the paper. Some aspects are touched upon in the paper but it could be more forcefully presented. Certainly the conclusions could usefully include these arguments to justify a greater research effort on Po. The first is that we must reduce reliance on traditional inorganic $P$ fertilisers (ie primary $P$ ) in the future, and strategies towards reducing reliance on soil inorganic $P$ fertility (ie lowering critical soil $P$ ) will increase the relevance of soil organic $P$ for providing available $\mathrm{P}$ for general ES provision. Secondly, the need to develop a circular $\mathrm{P}$ economy and close the $\mathrm{P}$ cycle will likely lead to an increase in the amounts of organic P bioresources (ie secondary $\mathrm{P}$ ) that are recycled to land in the future and this increased recycling of Po is potentially important for shifting the Po/Pi balance in the soil and the functionality of the soil microbial community and $\mathrm{C}$ sequestration.

This has now been emphasised in the conclusion text. 
More specific comments:

Line 70 - terrestrial environment is the scope here.

Information added.

Keywords = organic phosphorus needs to be included!

Added.

Line 117 - relative to inorganic $P$ forms Line 121 - why is phytase not mentioned here?

Added.

Line 123 - Is it worth mentioning that organic $\mathrm{N}$ is taken up by plants directly?

Added.

Line 140 - ecosystem resilience could be included in the list of global issues

Research priority 1 - the term 'real'-time' monitoring is not mentioned specifically but its hinted at in terms of linking forms to processes. Is this a possibility in the future or is the methodology too complex? Its there for Pi of course.

This wasn't seen as a realistic possibility by the consensus so was not included here.

Research priority 2 - para starting line 178 - why is there no mention of the CNP stoichiometry of crop plants here as they are competing for nutrient resources with the microbes?

Information added.

Line 208 - 'optimal stoichiometry' - its not clear here whether your just talking Po or total P?

Information added.

Research priority 3 - is it likely that Po will only really contribute to available P supply to crops when $\mathrm{Pi}$ has been depleted? Some clarification on current thoughts would be helpful here - eg line 259 .

\section{Clarification added.}

The first research opportunity in Table 1 is not covered in the text?

This was a priority identified by all groups in the process, but we did not highlight it in the text as the implications of this are more to do with the societal research model and beyond our scope here.

Table 1 highlights carbon sequestration as a global issue but the trade off between utilization of Po and $\mathrm{C}$ is not really discussed?

This is alluded to in section 3 when we discuss the use of organic $P$ as a nutrient source and is implicit in the stoichiometry discussion. 
What about the role of Po in the remediation of contaminated soils - heavy metals inputs etc.

This did not come up in any of the discussion groups and therefore did not make it into the consensus statements.

Overall this is a very welcome contribution from the P research community and I fully support publication. I have issues with including so many authors but that must be a decision for the editor!

Thank you again for the positive review of the paper and the authorship issue is discussed above in response to reviewer \#1 and editor comments. 
Click here to access/download

\section{Revised version including track changes \\ PS016_Final_Submitted_Revised_TrackedChanges.doc $\mathrm{X}$}


1

2

3

4

5

6

7

8

9

10

11

12

13

14

15

16

17

18

19

20

21

22

23

24

25

26

27

Organic phosphorus in the terrestrial environment: A perspective on the state of the art and future priorities

${ }^{1 *}$ George TS, ${ }^{1}$ Giles CD, ${ }^{2}$ Menezes-Blackburn D, ${ }^{3}$ Condron LM, ${ }^{4}$ Gama-Rodrigues AC, ${ }^{5}$ Jaisi D, ${ }^{6}$ Lang F, ${ }^{7}$ Neal AL,, Stutter MI, ${ }^{8}$ Almeida DS, ${ }^{9} \mathrm{Bol} \mathrm{R},{ }^{10}$ Cabugao KG, ${ }^{11} \mathrm{Celi} \mathrm{L},{ }^{12}$ Cotner JB, ${ }^{13} \mathrm{Feng} \mathrm{G},{ }^{14} \mathrm{Goll}$ DS, ${ }^{15}$ Hallama M, ${ }^{6}$ Krueger J, , ${ }^{16}$ Plassard C, ${ }^{17}$ Rosling A, ${ }^{7}$ Darch T, ${ }^{18}$ Fraser T, ${ }^{19}$ Giesler R, ${ }^{20}$ Richardson AE, ${ }^{21}$ Tamburini F, ${ }^{1}$ Shand CA, ${ }^{1}$ Lumsdon DG, ${ }^{2}$ Zhang H, ${ }^{7}$ Blackwell MSA, ${ }^{2}$ Wearing C, ${ }^{1}$ Mezeli MM, ${ }^{22}$ Almås ÅR, ${ }^{23}$ Audette Y, ${ }^{16}$ Bertrand I, ${ }^{24}$ Beyhaut E, ${ }^{3}$ Boitt G, ${ }^{25}$ Bradshaw N, ${ }^{26}$ Brearley CA, ${ }^{27}$ Bruulsema TW, ${ }^{14}$ Ciais P, ${ }^{28}$ Cozzolino V, ${ }^{29}$ Cuevas PD, ${ }^{29}$ Mora ML, ${ }^{30}$ de Menezes AB, ${ }^{31}$ Dodd RJ, ${ }^{23}$ Dunfield K, ${ }^{32}$ Engl C, ${ }^{33}$ Frazão JJ, ${ }^{21}$ Garland G, ${ }^{34}$ González Jiménez, JL, ${ }^{34}$ Graca J, ${ }^{7}$ Granger SJ, ${ }^{35}$ Harrison AF, ${ }^{36}$ Heuck C, ${ }^{37}$ Hou EQ, ${ }^{38}$ Johnes PJ, ${ }^{39}$ Kaiser K, ${ }^{40} \mathrm{Kjær} \mathrm{HA},{ }^{17} \mathrm{Klumpp} \mathrm{E},{ }^{41}$ Lamb AL, ${ }^{32}$ Macintosh KA, ${ }^{35}$ Mackay EB, ${ }^{32} \mathrm{McGrath} \mathrm{J},{ }^{38}$ McIntyre C, ${ }^{21}$ McLaren T, ${ }^{21}$ Mészáros E, ${ }^{9}$ Missong A, ${ }^{42}$ Mooshammer M, ${ }^{29}$ Negrón CP, ${ }^{43}$ Nelson L-A, ${ }^{7}$ Pfahler V, ${ }^{29}$ Poblete-Grant P, ${ }^{44}$ Randall M, ${ }^{29}$ Seguel A, ${ }^{3}$ Seth K, ${ }^{41}$ Smith AC, ${ }^{45}$ Smits MM, ${ }^{29}$ Sobarzo JA, ${ }^{36}$ Spohn M, ${ }^{46}$ Tawaraya K, ${ }^{18}$ Tibbett $\mathrm{M},{ }^{23}$ Voroney P, ${ }^{47}$ Wallander H, ${ }^{9}$ Wang L, ${ }^{48}$ Wasaki J,${ }^{2}$ Haygarth PM

${ }^{1}$ The James Hutton Institute, Dundee DD2 5DA and Aberdeen AB15 8QH, UK, ${ }^{2}$ Lancaster Environment Centre, Lancaster University, LA1 4YQ, UK, ${ }^{3}$ Lincoln University, Lincoln 7647, Christchurch, New Zealand, ${ }^{4}$ Universidade Estadual do Norte Fluminense Darcy Ribeiro (UENF - Laboratório de Solos), Av. Alberto Lamego 2000 Campos dos Goytacazes - RJ, Brasil, ${ }^{5}$ University of Delaware, Plant and Soil Sciences, 160 Townsend Hall, Newark, DE 19716 USA, ${ }^{6}$ University of Freiburg, Faculty of Environment and Natural Resources, Chair of Soil Ecology, Bertoldstraße 17, 79098 Freiburg, Germany, ${ }^{7}$ Rothamsted Research, West Common, Harpenden, Herts., AL5 2JQ \& North Wyke, Okehampton, Devon, EX20 2SB, UK ${ }^{8}$ Sao Paulo State University (UNESP), College of Agricultural Sciences, Department of Crop Science, 1780, Jose Barbosa de Barros st., Botucatu, Sao Paulo, Brazil, ${ }^{9}$ Institute of Bio- and Geosciences, IBG-3: Agrosphere, Forschungszentrum Jülich GmbH 52425 Jülich, Germany, ${ }^{10}$ Oak Ridge National Laboratory, P.O.Box 2008, Oak Ridge, TN 37831, USA ${ }^{11}$ DISAFA, Soil Biogeochemistry, University of Turin, largo Braccini 2, 10095 Grugliasco (TORINO), Italy, ${ }^{12}$ University of Minnesota-Twin Cities, 1479 Gortner Ave. Saint Paul, MN 55108, USA, ${ }^{13}$ China Agricultural University, Beijing, China ${ }^{14}$ Le Laboratoire des Sciences du Climat et de l'Environnement, IPSL-LSCE CEA/CNRS/UVSQ Saclay, Gif sur Yvette, France, ${ }^{15}$ Institute of Soil Science, University of Hohenheim, Emil Wolff Str. 27, D-70599 Stuttgart, Germany, ${ }^{16}$ INRA UMR ECO\&SOLS, Montpellier, France, ${ }^{17}$ Evolutionary Biology Centre, EBC, Kåbovägen 4, house 7, SE-752 36 Uppsala, Sweden, 
${ }^{18}$ Centre for Agri-environmental Research, School of Agriculture Policy and Development, University of Reading, Whiteknights, PO Box 237, Reading RG6 6AR, UK, ${ }^{19}$ Climate Impacts Research Centre, Dep. of Ecology and Environmental Science, Umeå University, 98107 Abisko, Sweden, ${ }^{20}$ CSIRO Agriculture \& Food, Canberra, Australia, ${ }^{21}$ D-USYS, ETH Zurich, Tannenstrasse 1, 8092 Zurich Switzerland, ${ }^{22}$ Norwegian University of Life Sciences, Department of Environmental Sciences Post Box 5003, 1432 Ås, Norway, ${ }^{23}$ University of Guelph, 50 Stone Road East, Guelph, Ontario, N1G 2W1, ${ }^{24}$ Instituto Nacional de Investigación Agropecuaria (INIA), Uruguay, ${ }^{25}$ Department of Chemical \& Biological Engineering, The University of Sheffield, Mappin Street, S1 3JD, UK, ${ }^{26}$ School of Biological Sciences, University of East Anglia, Norwich Research Park, Norwich, NR4 7TJ, Norfolk, United Kingdom, ${ }^{27}$ International Plant Nutrition Institute, 18 Maplewood Drive, Guelph, Ontario, Canada N1G 1L8, ${ }^{28}$ Centro Interdipartimentale di Ricerca sulla Risonanza Magnetica Nucleare per l'Ambiente, l'Agro-Alimentare ed i Nuovi Materiali (CERMANU), Università di Napoli Federico II, Via Università 100, 80055 Portici, Italy, ${ }^{29}$ Universidad de La Frontera, Chile ${ }^{30}$ School of Environment and Life Sciences, University of Salford, Greater Manchester, The Crescent, M5 4WT, UK, ${ }^{31}$ School of the Environment, Natural Resources and Geography, Bangor University, Gwynedd, LL57 2UW, UK, ${ }^{32}$ School of Biological Sciences and Institute for Global Food Security, The Queen's University of Belfast, Medical Biology Centre, 97 Lisburn Road, Belfast BT9 7BL, Northern Ireland, United Kingdom, ${ }^{33}$ CENA, University of Sao Paulo, Avenida Centenario, 303, 13416-000, Piracicaba, SP, Brazil, ${ }^{34}$ Teagasc, Environmental Research Centre, Johnstown Castle, Co. Wexford, Ireland, ${ }^{35}$ Centre for Ecology \& Hydrology, Library Avenue, Bailrigg, Lancaster, LA1 4AP, UK ${ }^{36}$ Department of Soil Biogeochemistry, Bayreuth Center of Ecology and Environmental Research (BayCEER), University Bayreuth, Dr.-Hans-Frisch-Str. 1-3, 95448 Bayreuth, Germany, ${ }^{37}$ Guangdong Provincial Key Laboratory of Applied Botany, South China Botanical Garden, Chinese Academy of Sciences, 723 Xingke Road, Tianhe District, Guangzhou 510650, China, ${ }^{38}$ School of Geographical Sciences \& School of Chemistry, University of Bristol, University Road, Bristol, BS8 1SS, UK ${ }^{39}$ Soil Science and Soil Protection, Martin Luther University Halle-Wittenberg, von-Seckendorff-Platz 3, 06120 Halle (Saale), Germany, ${ }^{40}$ Centre for Ice and Climate, Niels Bohr Institute, University of Copenhagen, ${ }^{41}$ NERC Isotope Geosciences Facility, British Geological Survey, Nottingham, NG12 5GG, UK., ${ }^{42}$ Department of Microbiology and Ecosystem Science, University of Vienna, Althanstrasse 14, 1090 Vienna, Austria ${ }^{43}$ University of Northern British Columbia, 3333 University Way, Prince George, BC, V2N 4Z9, Canada, ${ }^{44}$ Brigham Young University, Provo, UT 84602, USA, ${ }^{45}$ Centre for Environmental Sciences, Hasselt University Building D, Agoralaan 3590 Diepenbeek, Belgium, ${ }^{46}$ Yamagata University, Tsuruoka, 997-8555, Japan, 


\section{Abstract}

65 Background: The dynamics of phosphorus $(\mathrm{P})$ in the environment is important for regulating nutrient cycles in natural and managed ecosystems and an integral part in assessing biological resilience against environmental change. Organic $\mathrm{P}\left(\mathrm{P}_{\mathrm{o}}\right)$ compounds play key roles in biological and ecosystems function in the terrestrial environment, being critical to cell function, growth and reproduction.

Scope: We asked a group of experts to consider the global issues associated with $\mathrm{P}_{\mathrm{o}}$ - in the terrestrial environment, methodological strengths and weaknesses, benefits to be gained from understanding the $\mathrm{P}_{\mathrm{o}}$ cycle, and to set priorities for $\mathrm{P}_{\mathrm{o}}$ research.

Conclusions: We identified seven key opportunities for $\mathrm{P}_{\mathrm{o}}$ research including: the need for integrated, quality controlled and functionally based methodologies; assessment of stoichiometry with other elements in organic matter; understanding the dynamics of $\mathrm{P}_{\mathrm{o}}$ in natural and managed systems; the role of microorganisms in controlling $\mathrm{P}_{\mathrm{o}}$ cycles; the implications of nanoparticles in the environment and the need for better modelling and communication of the research. Each priority is discussed and a statement of intent for the $\mathrm{P}_{\mathrm{o}}$ research community is made that highlights there are key contributions to be made toward understanding biogeochemical cycles, dynamics and function of natural ecosystems and the management of agricultural systems.

\section{Keywords}

80 , Ecosystems services, Method development, Microbiome, Modelling, Organic Phosphorus, Stoichiometry.

\section{Abbreviations}


$88 \quad \mathrm{Fe}=$ Iron

$89 \quad \mathrm{~N}=$ Nitrogen

$90 \quad \mathrm{P}=$ Phosphorus

$91 \quad$ Pho $=$ Pho regulon transcription factors

$92 \quad \mathrm{P}_{\mathrm{i}}=$ Inorganic orthophosphate

$93 \quad \mathrm{P}_{\mathrm{o}}=$ Organic phosphate compounds

$94 \quad \mathrm{~S}=$ Sulphur

95

96

97

98

99

100

101

102

103

104

105

\section{The Importance of Phosphorus and Organic Phosphorus}

The dynamics of phosphorus $(\mathrm{P})$ in the terrestrial environment is critical for regulating nutrient cycling in both natural and managed ecosystems. Phosphorus compounds fundamentally contribute to life on earth: being essential to cellular organization as phospholipids, as chemical energy for metabolism in the form of ATP, genetic instructions for growth, development and cellular function as nucleic acids, and as intracellular signalling molecules (Butusov and Jernelöv 2013). Plant growth is limited by soil P availability, so turnover of organic phosphorus $\left(\mathrm{P}_{\mathrm{o}}\right)$ represents a source of $\mathrm{P}$ for ecosystem function and, critically, $\mathrm{P}$ supply affects crop production (Runge-Metzger 1995). Phosphorus deficiency constrains the accumulation and turnover of plant biomass and dictates community assemblages and biodiversity in a range of natural ecosystems (Attiwill and Adams 1993; McGill and Cole 1981).

Chemically, $\mathrm{P}$ is a complex nutrient that exists in many inorganic $\left(\mathrm{P}_{\mathrm{i}}\right)$ and organic $\left(\mathrm{P}_{\mathrm{o}}\right)$ forms in the environment. Through the utilization of orthophosphate, plants and other organisms drive the conversion of $\mathrm{P}_{\mathrm{i}}$ to $\mathrm{P}_{\mathrm{o}}$. Death, decay and herbivory facilitate the return of both $\mathrm{P}_{\mathrm{o}}$ and $\mathrm{P}_{\mathrm{i}}$ in plant materials to soil. Inputs of $\mathrm{P}$ to soil through these processes may contribute $\mathrm{P}_{\mathrm{o}}$ directly to soil or indirectly, following decomposition, accumulation, and stabilization of $\mathrm{P}_{\mathrm{o}}$ by microorganisms (Harrison 1982; Lang et al. 2016; Magid et al. 1996; McGill and Cole 

contains an organic moiety in addition to $\mathrm{P}$, while a wider definition would include phosphate which is associated with organic matter. Such discrete $\mathrm{P}_{\mathrm{o}}$ compounds are categorized into similarly structured forms and these forms and their relative lability in soil is shown in Figure 1, taken from Darch et al. (2014). The $P_{o}$ compounds, which are considered to be biologically relevant include monoesters, inositol phosphates, diesters and phosphonates. The relative lability and accumulation of these different groups varies in the environment, but overall the labile monoesters and diesters tend to be less prevalent and the inositol phosphates tend to be less labile and accumulate in the environment (Darch et al. 2014). In general, soil organic P forms have a smaller affinity to the soil solid phase than inorganic $\mathrm{P}$ forms and a large proportion of the $\mathrm{P}$ forms found in leachate are found to be in organic forms (Chardon \& Oenema, 1995; Chardon et al. 1997; Espinosa et al. 1999) and can therefore have large impacts on ecosystem function (Sharma et al. 2017; Toor et al. 2003). All $\mathrm{P}_{\mathrm{o}}$ compounds have a range of chemical bonds, and all require specific catalytic enzymes to make them biologically available in the form of orthophosphate. The hydrolysis of $\mathrm{P}_{\mathrm{o}}$ is mediated by the action of a suite of phosphatase enzymes which may have specificity for single compounds or broad specificity to a range of compounds (George et al. 2007). Unlike for organic nitrogen, there is no evidence for direct uptake of dissolved $\mathrm{P}_{\mathrm{o}}$ compounds by biology, apart from the uptake of phosphonates by bacteria in marine systems (Dyhrman et al. 2006). Plants and microbes possess a range of phosphatases that are associated with various cellular functions, including; energy metabolism, nutrient transport, metabolic regulation and protein activation (Duff et al. 1994). However, it is the extracellular phosphatases released into the soil that are of particular importance for the mineralisation of soil $\mathrm{P}_{\mathrm{o}}$. Extracellular phosphatase activity is induced under conditions of $\mathrm{P}$ deficiency and is either associated with root cell walls or released directly into the rhizosphere (Richardson et al. 2009).

There have been a number of important advances in our understanding of $\mathrm{P}_{\mathrm{o}}$ dynamics at the ecosystem and rhizosphere scale in the past decade, with particular advancement in understanding of plant-soil-microorganism interactions and concomitant advances in techniques used to assess these dynamics. It is now timely to start to consider how to integrate this information and extract further understanding of the dynamics of $\mathrm{P}_{\mathrm{o}}$ in the managed and natural environment and this will have a number of potentially important impacts on how we tackle some of the most pressing global issues of today. Here we summarise the state of the art of $\mathrm{P}_{\mathrm{o}}$ research and identify priorities for future research, which will help meet these goals. 
There has been a large increase in the number of publications in the $\mathrm{P}_{\mathrm{o}}$ research field in the last two decades, with 400 publications in 2016, compared to 150 in 2000. In September 2016 a workshop on Organic Phosphorus was held (https://op2016.com), gathering together 102 experts in the field of $\mathrm{P}_{\mathrm{o}}$ research from 23 countries to identify research priorities. Contributors were asked, in five groups, to consider the global issues associated with $\mathrm{P}_{\mathrm{o}}$, methodological strengths and weaknesses, benefits to be gained from understanding the $\mathrm{P}_{\mathrm{o}}$ cycle, and priorities for $\mathrm{P}_{\mathrm{o}}$ research. The information from the five groups was collected and the concepts, where consensus between at least two of the groups was reached, are summarized in Table 1. It is clear from this that research into $\mathrm{P}_{\mathrm{o}}$ has the potential to have impacts on global biogeochemical cycles of $\mathrm{P}$ both in natural and managed systems and will therefore potentially impact food security, agricultural sustainability, environmental pollution of both the aquatic and atmospheric environments and will be profoundly affected by environmental change both in geopolitical terms and through man-made climate change. We are well placed to tackle these as there are a number of strengths in the way the research is performed and the weaknesses are well understood. It was considered that $\mathrm{P}_{\mathrm{o}}$ research will have a range of impactful outcomes on our understanding of how natural and agricultural systems work and has the potential to give society a number of important tools to help manage the environment more effectively to either prevent or mitigate against some of the major global threats. A number of research priorities were identified and grouped into specific opportunities which are detailed below. The key opportunities to improve the effectiveness of $\mathrm{P}_{\mathrm{o}}$ research identified here are similar to those highlighted in Turner et al. (2005), although it is clear that some progress has been made since that set of recommendations were made. However, the similarities and consistency between the outcomes of these two studies suggests we still have some progress to make. A number of new priority areas were identified here that were not identified in Turner et al. (2005), including the need for greater understanding of the metagenomics and functional microbial genes involved in organic P turnover, greater understanding of the impact of nanoparticles in the environment on organic P turnover and the need to integrate the system more effectively in the form of models. It is clear that $\mathrm{P}_{\mathrm{o}}$ research field is evolving, but some of the issues of a decade ago still persist.

\section{1) Opportunities in organic phosphorus analytical methodologies}

The core analytical tools for the $\mathrm{P}_{\mathrm{o}}$ discipline are ${ }^{31} \mathrm{P}$ NMR spectroscopy (Cade-Menun and Liu 2014; CadeMenun 2005; Cade-Menun et al. 2005; Turner et al. 2005), which is used to identify $P_{o}$ compounds in several environmental matrices, along with more traditional soil extraction methods, such as those to measure total $\mathrm{P}_{\mathrm{o}}$ and the fractionation method developed by Hedley et al. (Condron and Newman 2011; Hedley et al. 1982; 
Negassa and Leinweber 2009). There is discussion and debate focused around the suitability of these analytical methodologies for characterizing $\mathrm{P}_{\mathrm{o}}$ in soil and terrestrial systems (Liu et al. 2014; Doolette and Smernik, 2011) and this debate revolves around the identity of the broad base of the inositol hexaphosphate peak on NMR spectra, which some contest is resolved and other suggest is unidentified (Jarosch et al. 2015). Despite this, research into $\mathrm{P}_{\mathrm{o}}$ is still limited methodologically and many methods are operationally-defined. Importantly, there is a need to link the results from these methods to biological and biogeochemical processes in the environment. In the process of achieving this, there is debate over the benefits of (i) standardization or homogenization of analytical methods, versus the merits of (ii) promoting diversity of analytical procedures.

It is critical to develop non-destructive methods to analyse soil pools and their dynamics without the need for extraction. Some solid-state methods, such as solid-state NMR or P-XANES (X-ray Adsorptive Near Edge Structure) spectroscopy are limited by the naturally low concentrations of $\mathrm{P}_{\mathrm{o}}$ forms in soils (Liu et al. 2013; 2014; 2015). Visible Near-Infrared Reflectance Spectroscopy (VNIRS) has shown some promise for determining total $\mathrm{P}_{\mathrm{o}}$ in soils (Abdi et al, 2016), but further testing is needed. Another priority for $\mathrm{P}_{\mathrm{o}}$ methodologies is the development of standard analytical quality controls through the use of standardized reference materials for cross-comparison and checks on analytical methods. These standardized reference materials will include reference soils and chemicals. There is a need for the community to identify standardized natural reference materials such as soils and manures, but a large amount of effort would be needed to put together a collection of appropriate materials as well as a means to share them internationally. Standardization of $\mathrm{P}_{\mathrm{o}}$ compounds could be achieved through the use of simple, relatively pure, and inexpensive $\mathrm{P}_{\mathrm{o}}$ compounds (e.g. Na-phytate, glucose 1-P) purchased from a single supplier operating in many countries with a guaranteed long-term production commitment. And there is a need to develop a commercial supply of other commonly identified $\mathrm{P}_{\mathrm{o}}$ compounds in soils, such as scyllo-inositol hexakisphosphate, to allow the use of appropriate substrates for research fully understand the biological and chemical processes controlling the behaviour of this and other $\mathrm{P}_{\mathrm{o}}$ compounds in the environment. It is a priority for researchers to further develop methods, while also refining existing $\mathrm{P}_{\mathrm{o}}$ methods and standards, to generate useful and comparable datasets and to build a consensus with respect to $\mathrm{P}_{\mathrm{o}}$ dynamics and function in agricultural and natural ecosystems. element cycles 
Comparing element ratios of living organisms and their non-living environment has been at the centre of

197

198

199

200

201

202

203

204

205

206

207

208

209

210

211

212

213

214

215

216

217

218

219

220

221

222

223

224 scientific debate for many years. In oceans, planktonic biomass is characterized by similar $\mathrm{C}: \mathrm{N}: \mathrm{P}$ ratios as marine water (106:16:1) (Redfield 1958). While similar characteristic element ratios also exist for terrestrial ecosystems with much greater heterogeneity across a range of spatial scales (Cleveland and Liptzin 2007). The comparison of $\mathrm{C}: \mathrm{N}: \mathrm{P}$ ratios in the microbial biomass of soils with that of soil organic matter (SOM) may therefore help to identify the nutrient status of the soil (Redfield 1958). Following this concept, the stoichiometric ratios of resources (e.g., SOM) over the microbial biomass has been calculated as a proxy for nutrient imbalances (Cleveland and Liptzin 2007). An understanding of stoichiometric ratios in soils and their relationship to those in crop plants and for the decomposition of litter and SOM will provide an important indicator of nutrient status in terrestrial ecosystems and better management of systems.

Until now, the large temporal and spatial heterogeneity of soil systems and the heterogeneous distribution of SOM constituents have made the analysis and interpretation of ecosystem stoichiometry a challenge because for microbial decomposers the elemental composition of micro-sites in soils might be more relevant than the overall element ratio of the soil. For example, by analysing the C:N:P ratio of bulk soils only, information on relevant and spatially-dependent processes may be lost (e.g., rhizosphere, soil horizons). The most obvious reason for soil-specificity and heterogeneity among stoichiometric ratios is that part of the SOM is separated from microorganisms and roots via physical and physicochemical barriers. By re-analysing the results of C:N:P:Sulphur (S) analyses of SOM obtained from 2000 globally distributed soil samples, Tipping et al. (2016) demonstrated that there is both nutrient-poor and nutrient-rich SOM, with the latter being strongly sorbed by soil minerals (Tipping et al. 2016). This may be explained by the incorporation of SOM into aggregates (Stewart and Tiessen 1987) or the adsorption of P-containing organic and inorganic molecules to mineral surfaces (Celi et al. 2003; Giaveno et al. 2010). Clay and metal (oxy)hydroxide minerals can sequester $\mathrm{P}_{\mathrm{o}}$ and $\mathrm{P}_{\mathrm{i}}$ released by microbial- or plant-driven processes and/or affect enzyme activities, while limiting $\mathrm{P}$ biocycling (Celi and Barberis 2005). This highlights the need to understand the tight interrelationship between chemical, physical and biological processes and the potential for stoichiometric assessment as an indicator of $\mathrm{P}$ and organic matter availability in soils. Modern analytical techniques which enable to analyse the stoichiometry of the soil constituents at a high resolution might help provide this knowledge (Mueller et al. 2012).

There are many known mechanisms by which organisms can improve access to $\mathrm{P}_{\mathrm{o}}$ (Richardson et al. 2011), but there are several novel mechanisms being identified that target key components of SOM, such as polyphenols 
and tannins, to mobilise $\mathrm{P}$ (Kohlen et al. 2011). A priority will be to understand the plant and microbial mechanisms involved in the accumulation and mobilization of $\mathrm{P}$ from organic matter. It is important to attempt to determine the optimal stoichiometry between $\mathrm{C}: \mathrm{N}: \mathrm{P}$, and understand the role $\mathrm{P}_{\mathrm{o}}$ plays in this, to allow sustainable management of $\mathrm{P}$ in arable soils and to identify anthropogenic nutrient imbalances in natural, agricultural and forest ecosystems (Frossard et al. 2015).

\section{3) Opportunities from understanding interactions of organic phosphorus with land management}

An ability to utilise $\mathrm{P}_{\mathrm{o}}$ to sustain agronomic productivity with declining conventional fertiliser inputs drives research into interactions among $\mathrm{P}_{\mathrm{o}}$, land use and management (Nash et al. 2014; Stutter et al. 2012). The conditions to better utilise $\mathrm{P}_{\mathrm{o}}$ may bring benefits for other soil quality factors (e.g., SOM status and microbial cycling), but may require management of potentially adverse effects on wider biological cycles and water quality (Dodd and Sharpley 2015). Societal drivers for food and timber production underpin much of the research into $\mathrm{P}_{\mathrm{o}}$ speciation, biological turnover and integration with agronomic systems. Numerous studies have reported $\mathrm{P}_{\mathrm{o}}$ stocks and changes associated with management; fewer have studied the time-course of transformations and turnover with management change, linked with soil chemical and biological processes. The interactions between $\mathrm{P}$ speciation, (bio)availability and SOM are of prime importance since land management greatly affects SOM in space and time (in beneficial or detrimental ways) and exert strong geochemical and microbial controls on Po cycling.

The interactions of land cover, use and management are important for understanding the role of $\mathrm{P}_{\mathrm{o}}$ across ecosystems. In agricultural systems, the information on soil $\mathrm{P}_{\mathrm{o}}$ stocks is well represented have been quantified by numerous studies in North America (Abdi et al. 2014; Cade-Menun et al. 2015; Liu et al. 2015; Schneider et al. 2016), Europe (Ahlgren et al. 2013; Annaheim et al. 2015; Keller et al. 2012; Stutter et al. 2015), China (Liu et al. 2013), South America (de Oliveira et al. 2015), and Australia (Adeloju et al. 2016). In forestry, such information is available in tropical (Zaia et al. 2012) and temperate systems (Slazak et al. 2010) and orchards (Cui et al. 2015). However, an important improvement will be to better understand the reasons as to why particular stocks exist under certain geoclimatic-land cover combinations. Key opportunities exist to understand $\mathrm{P}_{\mathrm{o}}$ dynamics for sustainable $\mathrm{P}$ use in tropical systems and for forests growing on marginal soils, both of which depend on effective management of $\mathrm{P}_{\mathrm{o}}$ resources.

It is known that both land cover and management factors (tillage, fertilizer type, application rate and timing) interact with abiotic factors in controlling $\mathrm{P}_{\mathrm{o}}$ stocks and cycling, such as SOM, stabilizing surfaces [e.g., Fe- and 

2015; Stutter et al. 2015). Chemical fractionation studies of $\mathrm{P}_{\mathrm{o}}$ stocks provide a snap-shot in time, missing temporal aspects of cycling associated with management-induced change at seasonal or to longer term management. As a result, short periods of rapid change in P speciation and turnover may not be appreciated. The utilization of 'legacy P' (Haygarth et al. 2014; Powers et al. 2016), following declining fertiliser inputs or altered cropping practices, has been studied following long-duration manipulations. Often these look at the end point of change (Cade-Menun et al. 2015), but have not 'followed' the dynamic. Although powerful methods for $\mathrm{P}_{\mathrm{o}}$ assessment are developing rapidly, studies that preceded these have the opportunity to incorporate them with archived samples or control soils (Keller et al. 2012; Liu et al. 2015). Long-term understanding of $P_{o}$ dynamics in management systems should be pursued, while short-term seasonal observations (for example Ebuele et al. 2016) will be needed to understand the influence of microbial dynamics on $P$ speciation and turnover under various land-use and management scenarios. If studies of short-term peturbations (via management, climate etc) can show benefits for providing greater $\mathrm{P}_{\mathrm{o}}$ resources into available pools then these processes may be beneficially incorporated in future land management.

'Organic' farming brings a commercial stimulus to substitute agro-chemicals (including chemical P fertilisers) with sustainable management, such as use of organic amendments, for example enhancing soil P cycling with the aim of better utilizing P already present and moving towards a 'closed' system (Annaheim et al. 2015; Gaind and Singh 2016; Schneider et al. 2016). The same approaches can be applied to less intensive, or developing, agricultural systems. Canadian pastures managed under an organic regime, had a greater abundance of $\mathrm{P}_{\mathrm{o}}(65 \%$ vs 52\% of total P)compared to conventional pastures and were able to maintain yield without inorganic fertilisers (Schneider et al. 2016). These authors concluded that plants were using $\mathrm{P}_{\mathrm{i}}$ rather than $\mathrm{P}_{\mathrm{o}}$ and supported by other studies showing no indication that the greater microbial activity under organic farming caused utilization of stabilized $P_{o}$ forms (Keller et al. 2012). Therefore, the management conditions and actions required to promote better acquisition of $\mathrm{P}_{\mathrm{o}}$ pools remain elusive.

The consensus is that a key question remains: How long could the turnover of $\mathrm{P}_{\mathrm{o}}$ sustain crop yields under scenarios of reduced $\mathrm{P}$ inputs and maintained or increased outputs and thus contribute to agricultural production and feed supplies? The mechanistic understanding required to answer this question lies in the role of biota (in the context of their abiotic setting) in $\mathrm{P}_{\mathrm{o}}$ turnover and the potential pathways of $\mathrm{P}_{\mathrm{o}}$ loss to be managed (e.g. runoff). In order to progress, a systems approach is needed to fully assess the opportunities and role of $\mathrm{P}_{\mathrm{o}}$, as 
well as the interactions of soil chemical, physical and biological processes and impacts of land use change that control P availability.

\section{4a) Opportunities from understanding microbial $P_{0}$ : functional genes and metagenomics}

286

287

288

289

290

291

292

293

294

295

296

297

298

299

300

301

302

303

304

305

306

307

308

309

310

311

As our abilities to analyse and interpret the complexity inherent in the soil microbiome improves, interest is burgeoning around the functional ecology of microorganisms. Organic P dynamics across ecosystems, along with development of many techniques that will aid in this understanding, are beginning to emerge. Scavenging of P from P-containing organic compounds by soil microbes is tightly controlled by intracellular P availability through the Pho pathway in yeast (Secco et al. 2012) and the Pho regulon in bacteria. In both cases, transcription of phosphatase and phytase, which act to release orthophosphate from phosphate esters, and high affinity transporters which transport $\mathrm{P}_{\mathrm{i}}$ into the cell, are up-regulated under $\mathrm{P}_{\mathrm{i}}$ limitation, affecting the organisms' ability to utilise $\mathrm{P}_{\mathrm{o}}$. The Pho regulon also acts as a major regulator of other cellular processes, including $\mathrm{N}$ assimilation and ammonium uptake (Santos-Beneit 2015). The C:N:P elemental ratios of the soil bacterium Bacillus subtilis range between $\mathrm{C}_{53-125}: \mathrm{N}_{12-29}: \mathrm{P}_{1}$ under $\mathrm{N}$ - and P-limited culture conditions (Dauner et al. 2001), although environmental assemblages may exhibit greater stoichiometric flexibility (Godwin and Cotner 2015). Given this regulatory cross-talk, nutrient stoichiometry will be important to cellular and community metabolism meaning that the cycling of P must be considered within the context of other biogeochemical cycles, as highlighted earlier.

Soil type, nutrient inputs, and plant species have been shown to determine microbiota species composition and function (Alegria-Terrazas et al. 2016). However, plant root exudation drives recruitment of specific microbes and microbial consortia to the rhizosphere and may outweigh the impacts of soil and its management in shaping community composition and function (Tkacz et al. 2015). As yet, there is only limited understanding of how specific root exudates affect microbial recruitment (Neal et al. 2012), let alone specific microbiota responsible for phosphatase expression and production. A better understanding of interactions between plants and microbes would facilitate identification of functional redundancy among them, which could ultimately help manage the availability of $\mathrm{P}$ in soils and sediments by selection of the optimal plant rhizosphere compliment.

Alkaline phosphatase and phytase genes are distributed across a broad phylogenetic range and display a high degree of microdiversity (Jaspers and Overmann 2004; Lim et al. 2007; Zimmerman et al. 2013), where closely related organisms exhibit different metabolic activities. It is therefore not possible to determine community functional potential from 16S rRNA gene abundance - functional gene abundance information is required and 
this can be provided by employing sequencing techniques to assess the soil metagenome. In marine systems,

313 there is evidence from metagenomic sequencing of environmental DNA that alkaline phosphatase genes phoD and phoX are more abundant than phoA (Luo et al. 2009; Sebastian and Ammerman 2009) and the $\beta$-propeller phytase is the most abundant phytase gene (Lim et al. 2007). The dominant alkaline phosphatase gene in terrestrial ecosystems is also phoD (Tan et al. 2013), which is more abundant in soils than other environments (Courty et al. 2010; Ragot et al. 2015; Fraser et al. 2017). From a functional standpoint, abundance of phoD-like sequences correlate well with estimates of potential alkaline phosphatase activity (Fraser et al. 2015), although this is not always the case (Ragot et al. 2015).Moreover, in soils there is little information regarding other phosphatases and little is known about the distribution and abundance of bacterial acid phosphatases, but there is some information related to phoX (Ragot et al. 2016). In contrast, fungi are well known for their capacity to secrete acid phosphatases (Plassard et al. 2011; Rosling et al. 2016), especially ectomycorrhizal fungi. Since only a small percentage of soil microorganisms are cultivable, research will need to rely upon cultureindependent approaches to generate a thorough understanding of the abundance and diversity of genes associated with $\mathrm{P}_{\mathrm{o}}$ turnover. Environmental metagenomic sequencing can form the basis of an efficient molecular toolkit for studying microbial gene dynamics and processes relevant to $\mathrm{P}_{\mathrm{o}}$ mineralization (Neal et al., 2017). Such an approach will need to prioritize generating comprehensive understanding of the distribution of alkaline and acid phosphatase and phytase genes within soils, coupled with activity measurements, and a sense of their relative sensitivities to edaphic factors. This will allow explicit incorporation of microbial $\mathrm{P}_{\mathrm{o}}$ turnover in the new generation of soil models, as well as allowing rapid assessment of a soil's capabilities for $\mathrm{P}_{\mathrm{o}}$ cycling. Improved knowledge will allow the exploitation of microbial activity to sustain and improve soil fertility and allow the tailoring of new fertilizers based upon the capacity of microbes to exploit $\mathrm{P}_{\mathrm{o}}$. turnover

The apparently large diversity of genes associated with $\mathrm{P}_{\mathrm{o}}$-hydrolysing enzymes suggests that changes in community composition are unlikely to result in a loss of ecosystem function. This confers resilience to Pcycling processes, although many of these genes have very specific functions intracellularly. However, trait differences are likely to have significant implications for community function in soils, e.g., the contrasting effects of arbuscular and ectomycorrhizal fungi upon the cycling of $\mathrm{P}$ in forest soils, where it has been shown 

apparent influence of the Pho regulon or pathway upon gene expression and indicates that much of the observed activity derives from multiple enzyme sources, which have been stabilised by soil colloids (Nannipieri et al. 2011). This also suggests that soil enzyme activity does not directly represent microbial activity or simply reflects the complexity in current $\mathrm{P}$ requirements of different microbial species. However, visualization of acid and alkaline phosphatase activity associated with roots by zymography (Spohn and Kuzyakov 2013) does provide an exciting means to determine regulation of soil phosphatase activity with $\mathrm{P}$ availability and illustrates the clear spatial separation among the activities of physiologically different enzymes. It is a priority to develop and couple techniques that resolve the distribution of active enzymes in soil with estimates of gene expression derived from functional genes or meta-transcriptomic studies.

The stock of microbial $\mathrm{P}$ is an easy-to-determine component in soils, which is widely used to characterize the $\mathrm{P}$ status of microbial communities and ecosystems (Brookes et al. 1982; 1984). Nevertheless, its analysis relies on many different protocols (Bergkemper et al. 2016). Building on the previous work, further insights into both microbial-mediated and enzyme-mediated $\mathrm{P}$ transformations in soils may now be gained from measurement of the isotopic composition of oxygen associated with phosphate $\left(\delta^{18} \mathrm{OP}\right)$ (Tamburini et al. 2014; von Sperber et al. $2014)$ and the use of radiolabelled $\left({ }^{32} \mathrm{P}\right.$ or $\left.{ }^{33} \mathrm{P}\right) \mathrm{P}_{\mathrm{o}}$ compounds to measure mineralisation and immobilisation rates directly (Harrison 1982). A powerful tool for quantifying soil $\mathrm{P}$ pools and transformation rates is the isotope dilution technique [reviewed in Bünemann 2015; Di et al. 2000; Frossard et al. 2011]. The decrease in radioactivity with time is caused by the exchange of the added radiolabelled $\mathrm{P}$ (either ${ }^{32} \mathrm{P}$ or ${ }^{33} \mathrm{P}$ ) with ${ }^{31} \mathrm{P}$ from the sorbed/solid phase and by the release of inorganic ${ }^{31} \mathrm{P}$ from the organic pool via hydrolysing enzymes (Bünemann 2015). Determination of gross $P_{o}$ mineralization rates from $P_{o}$ to $P_{i}$ remains a critical approach, helping understand the processes and rates of $\mathrm{P}$ cycling in different soils and under different environmental conditions (Frossard et al. 2011). These techniques present new opportunities to link $\mathrm{P}$ cycling to other biogeochemical cycles, such as $\mathrm{C}$ and $\mathrm{N}$.

\section{5) Opportunities in the emerging area of interactions between $P_{0}$ dynamics and nanoparticles}

Reactive nanoparticles can take the form of natural soil colloids or man-made particles and are potential $\mathrm{P}_{\mathrm{o}}$ carriers, sources and sinks in ecosystems. Up to $90 \%$ of $\mathrm{P}$ in stream water and runoff is present in nano- and colloidal sized materials (Borda et al. 2011; Gottselig et al. 2014; Uusitalo et al. 2003; Withers et al. 2009). 

on the dynamics and bioavailability of P in soil-plant systems is unclear (Bol et al. 2016). Nanoparticles such as C-magnetite, which adsorb and retain $\mathrm{P}_{\mathrm{i}}$ and $\mathrm{P}_{\mathrm{o}}$, are used to enhance the recovery and recycling of $\mathrm{P}$ from $\mathrm{P}$-rich wastes (Magnacca et al. 2014; Nisticò et al. 2016). It may also be possible to enhance soil enzyme activity with amendments containing mesoporous nanoparticle materials (Zhou and Hartmann 2012). Phytase encapsulated in nanoparticles was shown to be resistant to inhibitors and proteases and to promote the hydrolysis of phytate for P uptake by Medicago truncatula (Trouillefou et al. 2015). Nanotechnology has also been used to develop new fertilizers and plant-growth-enhancing materials (Liu and Lal 2015), representing one potentially effective option for enhancing global food production. A better understanding of the $\mathrm{P}_{\mathrm{o}}$ nanoparticle interaction may improve our understanding on $\mathrm{P}$ fluxes in natural and agricultural systems, and provide innovative technologies for fertilizer production and environmental remediation.

\section{6) Opportunities to use modelling of $P_{0}$ in soil and ecosystems}

The use of all types of modelling approaches to study $\mathrm{P}_{\mathrm{o}}$ is generally overlooked and there is a dearth of $\mathrm{P}_{\mathrm{o}}$ based models, but development of such models would be extremely beneficial. Modelling should facilitate the development of a systems-based perspective and help to identify knowledge gaps in the current understanding of $\mathrm{P}_{\mathrm{o}}$. Models of all types are needed including those that are conceptual, mechanistic or empirical in nature and in general there is a lack of focus on all the types of models that exist for $\mathrm{P}_{\mathrm{o}}$. The potential benefits of advances in modelling for $\mathrm{P}_{\mathrm{o}}$ include:

- Prediction of the relationship between soil $\mathrm{P}_{\mathrm{o}}$ and plant uptake, which should be developed in both conceptual and mechanistic models of $\mathrm{P}$ dynamics in the environment.

- Application at different scales to determine the relationship between $\mathrm{P}_{\mathrm{o}}$ with land use and management should be possible by building empirical models based on existing data.

- Application of modelling to help understand the role of microbial traits in soil (Wieder et al. 2015), which

- Application of complete Life-Cycle Analysis for relying of the run-down of soil $\mathrm{P}_{\mathrm{o}}$ as a replacement to inorganic fertilisers will help us develop adequate conceptual models for management of the system.

- Modelling could also be used to help in the quantification of soil $\mathrm{P}$ pools for estimating flow among $\mathrm{P}_{\mathrm{o}}$ pools. 
399

400

401

402

403

404

405

406

407

408

409

410

411

412

413

414

415

416

417

418

419

420

421

422

423

424

425

426

427

In general, there is a great opportunity for the development of modelling in all areas of $\mathrm{P}_{\mathrm{o}}$ research and this will be of considerable benefit to the subject if this can be developed and integrated with all areas. The cooperation of modellers and empiricists is essential for building models with great potential use to predict changes in $\mathrm{P}_{\mathrm{o}}$ bioavailability due to land-use and management change and to infer the sustainability of the system as a whole.

\section{7) Opportunities to better communicate and translate research}

Organic P represents a small, albeit critical component of biogeochemical research. The marginal nature of the subject to date creates a need to communicate the importance of this science for the future of P sustainability. As for other scientific disciplines, communication priorities include (1) strengthening communication among scientists within and outside of the $\mathrm{P}_{\mathrm{o}}$ research community; (2) engagement with stakeholders; and (3) dissemination of knowledge to the public and specific end-users.

Conferences and workshops on the topic of organic P promote the exchange of ideas and forging of new research partnerships (Sharpley et al. 2015; Turner et al. 2015). Online platforms are also powerful tools to connect researchers and stakeholders on issues of global P sustainability (e.g., European Sustainable Phosphorus Platform, www.phosphorusplatform.eu, North America Partnership for Phosphorus Sustainability) (Rosemarin and Ekane 2015). The ‘Soil Phosphorus Forum' (www.soilpforum.com) provides a platform for the exchange of information relating to $\mathrm{P}_{\mathrm{o}}$. Specific protocols and conference presentations are also featured in archived YouTube channels (https://www.youtube.com/channel/UCtGI3eUZscCgByewafsQKdw). A central platform for $\mathrm{P}_{\mathrm{o}}$ research and communications is still needed, to connect existing forums to global research networks and would include features such as researcher membership, methodological resources, links to relevant organizations and platforms, and a clearing house of $\mathrm{P}_{\mathrm{o}}$ data for future meta-analysis and modelling efforts.

Key stakeholder groups such as land managers, farmers and extension services are a natural link between industry, government, and academia (FAO 2016). These key groups hold traditional knowledge on sustainable farming techniques, which serve as a potential basis for future $\mathrm{P}_{\mathrm{o}}$ research. Industry initiatives such as the $4 \mathrm{R}$ Nutrient Stewardship framework provide feedback from end users and practitioners on research priorities associated with the management of agricultural nutrients (Vollmer-Sanders et al. 2016). The engagement of $P_{o}$ researchers with existing nutrient initiatives such as these will be critical for bolstering public understanding of $\mathrm{P}_{\mathrm{o}}$ and its important role in global $\mathrm{P}$ dynamics. 
429 Organic P research has a critical role to play in tackling a number of important global challenges and there are 430 key contributions to be made toward understanding biogeochemical cycles, dynamics and function of natural 431 ecosystems and the management of agricultural systems. In particular, we must reduce our reliance on inorganic $432 \mathrm{P}$ fertilisers and strategies to do this will increase the relevance of soil $\mathrm{P}_{\mathrm{o}}$ for plant nutrition. Secondly, there is a 433 need to develop a circular P economy and close the P cycle which will likely lead to an increase in the amounts 434 of organic $\mathrm{P}$ "waste" products being recycled to land shifting the $\mathrm{P}_{\mathrm{o}} / \mathrm{P}_{\mathrm{i}}$ balance in the soil. To address these 435 global environmental changes and challenges, we should concentrate our efforts on understanding the biological significance of $\mathrm{P}_{\mathrm{o}}$ by considering its interactions with other elements in SOM, soil microorganisms and active soil surfaces. We should consider these interactions with respect to changes in land use and management and as a function of geochemical conditions in the wider biophysical and socio-economic environment. We need to integrate this understanding through the production of models for $\mathrm{P}_{\mathrm{o}}$, which capture both whole systems and fine-scale mechanisms. In addition, we need to develop novel and standardised methodologies that can integrate the dynamics and function of $\mathrm{P}_{\mathrm{o}}$ on appropriate scales in a non-invasive manner. To achieve a step-change in the impact of $P_{o}$ research, we need to engage with researchers outside of the discipline, align the research with pressing societal issues, and become more global, collaborative, inclusive, interdisciplinary, and longer-term in nature. The key to fostering this change will depend on logically communicating the importance of $\mathrm{P}_{\mathrm{o}}$ to society at large, engaging with stakeholders on important global issues, and ultimately pushing this important area of research up the agenda of policy makers and funding bodies on a global scale.

\section{Acknowledgements}

448 This work was performed with the financial support of the Organic Phosphorus Utilisation in Soils (OPUS) project, funded by Biotechnology and Biological Sciences Research Council (BBSRC - BBSRC BB/K018167/1) in the UK and the Rural \& Environment Science \& Analytical Services Division of the Scottish

451 Government. Fraser and Tibbett acknowledge the support of BBSRC SARISA programme BB/L025671/2. We also acknowledge the contribution to the output of the OP2016 workshop of all the attendees of the meeting who chose not be named as an author on this paper. In particular, the authors would like to thank Barbara CadeMenun and Ben Turner and acknowledge there contribution to drafts of this manuscript. 
Abdi D, Cade-Menun BJ, Ziadi N, Parent L-É (2014) Long-Term Impact of Tillage Practices and Phosphorus Fertilization on Soil Phosphorus Forms as Determined by 31P Nuclear Magnetic Resonance Spectroscopy. J Environ Qual 43: 1431-1441. doi: 10.2134/jeq2013.10.0424.

Abdi D, Cade-Menun BJ, Ziadi N, Tremblay GF, Parent LÉ (2016) Visible near infrared reflectance spectroscopy to predict soil phosphorus pools in chernozems of Saskatchewan, Canada. Geoderma Region 7: 93-101.

Adeloju S, Webb B, Smernik R (2016) Phosphorus Distribution in Soils from Australian Dairy and Beef Rearing Pastoral Systems. Appl Sci 6: 31.

Ahlgren J, Djodjic F, Börjesson G, Mattsson L (2013) Identification and quantification of organic phosphorus forms in soils from fertility experiments. Soil Use and Management 29: 24-35. doi: 10.1111/sum.12014.

Alegria-Terrazas R, Giles CD, Paterson E, Robertson-Albertyn S, Cesco S, Mimmo T, Pii Y, Bulgarelli D (2016) Plant-Microbiota Interactions as a Driver of the Mineral Turnover in the Rhizosphere. Adv Appl Microbiol. Springer.

Annaheim KE, Doolette AL, Smernik RJ, Mayer J, Oberson A, Frossard E, Bünemann EK (2015) Long-term addition of organic fertilizers has little effect on soil organic phosphorus as characterized by 31P NMR spectroscopy and enzyme additions. Geoderma 257-258: 67-77. doi: http://dx.doi.org/10.1016/j.geoderma.2015.01.014.

Attiwill PM, Adams MA (1993) Nutrient cycling in forests. New Phytol 124: 561-582. doi: 10.1111/j.14698137.1993.tb03847.x.

Bergkemper F, Bünemann EK, Hauenstein S, Heuck C, Kandeler E, Krüger J, Marhan S, Mészáros É, Nassal D, Nassal P, Oelmann Y, Pistocchi C, Schloter M, Spohn M, Talkner U, Zederer DP, Schulz S (2016) An inter-laboratory comparison of gaseous and liquid fumigation based methods for measuring microbial phosphorus (Pmic) in forest soils with differing P stocks. J Microbiol Methods 128: 66-68. doi: http://dx.doi.org/10.1016/j.mimet.2016.07.006.

Bol R, Julich D, Brödlin D, Siemens J, Kaiser K, Dippold MA, Spielvogel S, Zilla T, Mewes D, von Blanckenburg F, Puhlmann H, Holzmann S, Weiler M, Amelung W, Lang F, Kuzyakov Y, Feger K-H, Gottselig N, Klumpp E, Missong A, Winkelmann C, Uhlig D, Sohrt J, von Wilpert K, Wu B, Hagedorn F (2016) Dissolved and colloidal phosphorus fluxes in forest ecosystems - an almost blind spot in ecosystem research. J Plant Nutr Soil Sci 179: 425-438. doi: 10.1002/jpln.201600079. 

suspended solids and phosphorus losses from soil to waters. J Soils Seds 11: 440-451. doi: 10.1007/s11368-010-0327-y.

Brookes PC, Powlson DS, Jenkinson DS (1982) Measurement of microbial biomass phosphorus in soil. Soil Biol Biochem 14: 319-329. doi: http://dx.doi.org/10.1016/0038-0717(82)90001-3.

Brookes PC, Powlson DS, Jenkinson DS (1984) Phosphorus in the soil microbial biomass. Soil Biol Biochem 16: 169-175. doi: http://dx.doi.org/10.1016/0038-0717(84)90108-1.

Bünemann EK (2015) Assessment of gross and net mineralization rates of soil organic phosphorus - A review. Soil Biology Biochem 89: 82-98. doi: 10.1016/j.soilbio.2015.06.026.

Butusov M, Jernelöv A (2013) Phosphorus in the Organic Life: Cells, Tissues, Organisms. Phosphorus: An Element that could have been called Lucifer. Springer New York, New York, NY.

Cade-Menun B, Liu CW (2014) Solution phosphorus-31 nuclear magnetic resonance spectroscopy of soils from 2005 to 2013: A review of sample preparation and experimental parameters. Soil Sci Soc Am J 78: 1937. doi: $10.2136 /$ sssaj2013.05.0187dgs.

Cade-Menun BJ (2005) Characterizing phosphorus in environmental and agricultural samples by $31 \mathrm{P}$ nuclear magnetic resonance spectroscopy. Talanta 66: 359-371.

Cade-Menun BJ, He Z, Zhang H, Endale DM, Schomberg HH, Liu CW (2015) Stratification of Phosphorus Forms from Long-Term Conservation Tillage and Poultry Litter Application. Soil Sci Soc Am J 79: 504-516. doi: 10.2136/sssaj2014.08.0310.

Celi L, De Luca G, Barberis E (2003) Effects of interaction of organic and inorganic P with ferrihydrite and kaolinite-iron oxide systems on iron release. Soil Sci 168: 479-488. 

for Agrobiology and Soil Fertility.

Chardon WJ, Oenema O, del Castilho P, Vriesema R, Japenga J, Blaauw D (1997) Organic phosphorus in solutions and leachates from soils treated with animal slurries. J. Environ. Q. 26: 372-378.

Cleveland CC, Liptzin D (2007) C:N:P stoichiometry in soil: is there a "Redfield ratio" for the microbial biomass? Biogeochem 85: 235-252. doi: 10.1007/s10533-007-9132-0.

Condron LM, Newman S (2011) Revisiting the fundamentals of phosphorus fractionation of sediments and soils. J Soils Seds 11: 830-840. doi: 10.1007/s11368-011-0363-2.

Courty P-E, Franc A, Garbaye J (2010) Temporal and functional pattern of secreted enzyme activities in an ectomycorrhizal community. Soil Biol Biochem 42: 2022-2025. doi: 10.1016/j.soilbio.2010.07.014.

Cui H, Zhou Y, Gu Z, Zhu H, Fu S, Yao Q (2015) The combined effects of cover crops and symbiotic microbes on phosphatase gene and organic phosphorus hydrolysis in subtropical orchard soils. Soil Biology and Biochemistry 82: 119-126. doi: 10.1016/j.soilbio.2015.01.003.

Darch T, Blackwell MSA, Hawkins JMB, Haygarth PM, Chadwick D (2014) A Meta-Analysis of Organic and Inorganic Phosphorus in Organic Fertilizers, Soils, and Water: Implications for Water Quality. Crit Rev

de Oliveira CMB, Erich MS, Gatiboni LC, Ohno T (2015) Phosphorus fractions and organic matter chemistry

Dodd RJ, Sharpley AN (2015) Recognizing the role of soil organic phosphorus in soil fertility and water quality. Res Conserv Recycl 105, Part B: 282-293. doi: 10.1016/j.resconrec.2015.10.001.

Dauner M, Storni T, Sauer U (2001) Bacillus subtilis Metabolism and Energetics in Carbon-Limited and Excess-Carbon Chemostat Culture. J Bacteriol 183: 7308-7317. doi: 10.1128/JB.183.24.73087317.2001. under different land use on Humic Cambisols in Southern Brazil. Geoderma Regional 5: 140-149. doi: http://dx.doi.org/10.1016/j.geodrs.2015.06.001.

Di HJ, Cameron KC, McLaren RG (2000) Isotopic dilution methods to determine the gross transformation rates of nitrogen, phosphorus, and sulfur in soil: a review of the theory, methodologies, and limitations. Soil Res 38: 213-230. doi: http://dx.doi.org/10.1071/SR99005.

Doolette AL, Smernik RJ. (2011) Soil organic phosphorus speciation using spectroscopic techniques. In Phosphorus in action, Springer Berlin Heidelberg pp. 3-36 
Duff SM, Sarath G, Plaxton WC (1994) The role of acid phosphatases in plant phosphorus metabolism. Physiol. Plant. 90: 791-800.

Dyhrman ST, Chappell PD, Haley ST, Moffett JW, Orchard ED, Waterbury JB, Webb EA. (2006) Phosphonate utilization by the globally important marine diazotroph Trichodesmium. Nature. 439: 68 .

Ebuele VO, Santoro A, Thoss V (2016) Phosphorus speciation by 31P NMR spectroscopy in bracken (Pteridium aquilinum (L.) Kuhn) and bluebell (Hyacinthoides non-scripta (L.) Chouard ex Rothm.) dominated semi-natural upland soil. Sci Tot Environ 566-567: 1318-1328. doi: 10.1016/j.scitotenv.2016.05.192.

Espinosa M, Turner B, Haygarth P (1999) Preconcentration and separation of trace phosphorus compounds in soil leachate. J. Environ Q 28: 1497-1504.

Food and Agricultural Organization of the United Nations (2016). Research and Extension. http://www.fao.org/nr/research-extension-systems/res-home/en/. Date Accessed: 13 October 2016.

Fraser T, Lynch DH, Entz MH, Dunfield KE (2015) Linking alkaline phosphatase activity with bacterial phoD gene abundance in soil from a long-term management trial. Geoderma 257-258: 115-122. doi: 10.1016/j.geoderma.2014.10.016.

Fraser TD, Lynch DH, Gaiero J, Khosla K, Dunfield KE. (2017) Quantification of bacterial non-specific acid (phoC) and alkaline (phoD) phosphatase genes in bulk and rhizosphere soil from organically managed soybean fields. Applied Soil Ecology 111:48-56.

Frossard E, Buchmann N, Bünemann EK, Kiba DI, Lompo F, Oberson A, Tamburini F, Traoré OY. (2015) Soil

Gaind S, Singh YV (2016) Soil organic phosphorus fractions in response to long-term fertilization with 
George TS, Simpson RJ, Gregory PJ, Richardson AE (2007) Differential interaction of Aspergillus niger and Peniophora lycii phytases with soil particles affects the hydrolysis of inositol phosphates. Soil Biol. Biochem. 39: 793-803.

Giaveno C, Celi L, Richardson AE, Simpson RJ, Barberis E (2010) Interaction of phytases with minerals and availability of substrate affect the hydrolysis of inositol phosphates. Soil Biol Biochem 42: 491-498. doi: 10.1016/j.soilbio.2009.12.002.

Godwin CM, Cotner JB (2015) Aquatic heterotrophic bacteria have highly flexible phosphorus content and biomass stoichiometry. ISME J 9: 2324-2327. doi: 10.1038/ismej.2015.34.

Gottselig N, Bol R, Nischwitz V, Vereecken H, Amelung W, Klumpp E (2014) Distribution of PhosphorusContaining Fine Colloids and Nanoparticles in Stream Water of a Forest Catchment. Vadose Zone J 13. doi: 10.2136/vzj2014.01.0005.

Harrison AF (1982) 32P-method to compare rates of mineralization of labile organic phosphorus in woodland soils. Soil Biol Biochem14: 337-341. doi: 10.1016/0038-0717(82)90003-7.

Haygarth PM, Jarvie HP, Powers SM, Sharpley AN, Elser JJ, Shen J, Peterson HM, Chan NI, Howden NJ, Burt T, Worrall F, Zhang F, Liu X (2014) Sustainable phosphorus management and the need for a long-term perspective: the legacy hypothesis. Environ Sci Technol 48: 8417-8419. doi: 10.1021/es502852s.

Hedley MJ, Stewart JWB, Chauhuan BS (1982) Changes in inorganic and organic soil phosphorus fractions induced by cultivation practices and by laboratory incubations. Soil Sci Soc Am J 46: 970-976.

Jarosch KA, Doolette AL, Smernik RJ, Tamburini F, Frossard E, Bünemann EK.(2015) Characterisation of soil organic phosphorus in NaOH-EDTA extracts: a comparison of 31 P NMR spectroscopy and enzyme addition assays. Soil Biology and Biochemistry 91:298-309.

Jaspers E, Overmann J (2004) Ecological Significance of Microdiversity: Identical 16S rRNA Gene Sequences Can Be Found in Bacteria with Highly Divergent Genomes and Ecophysiologies. Appl Environ Microbiol 70: 4831-4839. doi: 10.1128/AEM.70.8.4831-4839.2004.

Jiang X, Bol R, Willbold S, Vereecken H, Klumpp E (2015) Speciation and distribution of P associated with Fe and $\mathrm{Al}$ oxides in aggregate-sized fraction of an arable soil. Biogeosci 12: 6443-6452. doi: 10.5194/bg12-6443-2015.

Keller M, Oberson A, Annaheim KE, Tamburini F, Mäder P, Mayer J, Frossard E, Bünemann EK (2012) Phosphorus forms and enzymatic hydrolyzability of organic phosphorus in soils after 30 years of 

10.1002/jpln.201100177.

Kohlen W, Charnikhova T, Liu Q, Bours R, Domagalska MA, Beguerie S, Verstappen F, Leyser O,

604

605

606

607

608

609

610

611

612

613

614

615

616

617

618

619

620

621

622

623

624

625

626

627

628

629

630 Bouwmeester H, Ruyter-Spira C (2011) Strigolactones are transported through the xylem and play a key role in shoot architectural response to phosphate deficiency in nonarbuscular mycorrhizal host Arabidopsis. Plant physiol155: 974-987. doi: 10.1104/pp.110.164640.

Lang F, Bauhus J, Frossard E, George E, Kaiser K, Kaupenjohann M, Krüger J, Matzner E, Polle A, Prietzel J, Rennenberg H, Wellbrock N (2016) Phosphorus in forest ecosystems: New insights from an ecosystem nutrition perspective. J Plant Nutri Soil Sci 179: 129-135. doi: 10.1002/jpln.201500541.

Lim BL, Yeung P, Cheng C, Hill JE (2007) Distribution and diversity of phytate-mineralizing bacteria. ISME 1: 321-330. doi: 10.1038/ismej.2007.40.

Liu J, Hu Y, Yang J, Abdi D, Cade-Menun BJ (2015) Investigation of soil legacy phosphorus transformation in long-term agricultural fields using sequential fractionation, P K-edge XANES and solution P NMR spectroscopy. Environ Sci Technol 49: 168-176. doi: 10.1021/es504420n.

Liu J, Yang J, Cade-Menun BJ, Liang X, Hu Y, Liu CW, Zhao Y, Li L, Shi J (2013) Complementary Phosphorus Speciation in Agricultural Soils by Sequential Fractionation, Solution 31P Nuclear Magnetic Resonance, and Phosphorus K-edge X-ray Absorption Near-Edge Structure Spectroscopy. J Environ Qual 42: 1763-1770. doi: 10.2134/jeq2013.04.0127.

Liu J, Hu Y, Yang J, Abdi D, Cade-Menun BJ (2014) Investigation of soil legacy phosphorus transformation in long-term agricultural fields using sequential fractionation, P K-edge XANES and solution P NMR spectroscopy. Environ Sci \& Tech. 49:168-76.

Liu R, Lal R (2015) Potentials of engineered nanoparticles as fertilizers for increasing agronomic productions. Science of The Total Environment 514: 131-139. doi: 10.1016/j.scitotenv.2015.01.104.

Luo H, Benner R, Long RA, Hu J (2009) Subcellular localization of marine bacterial alkaline phosphatases. PNAS 106: 21249-21223.

Magid J, Tiessen H, Condron LM (1996) Humic substances in terrestrial ecosystems. In: A Piccolo (ed) Dynamics of organic phosphorus in soils under natural and agricultural ecosystems. Elsevier Science, Amsterdam.

Magnacca G, Allera A, Montoneri E, Celi L, Benito DE, Gagliardi LG, Gonzalez MC, Mártire DO, Carlos L (2014) Novel Magnetite Nanoparticles Coated with Waste-Sourced Biobased Substances as 

1524. doi: $10.1021 / \mathrm{sc} 500213 \mathrm{j}$.

McGill WB, Cole CV (1981) Compartive aspects of cycling of organic C, N, S and P through soil organic matter. Geoderma 26: 267-286.

Mueller CW, Kölbl A, Hoeschen C, Hillion F, Heister K., Herrmann AM, Kögel-Knabner I (2012). Submicron scale imaging of soil organic matter dynamics using NanoSIMS-from single particles to intact aggregates. Org. Geochem. 42: 1476-1488.

Nannipieri P, Giagnoni L, Landi L, Renella G (2011) Role of Phosphatase Enzymes in Soil. In: E Bünemann, A Oberson, E Frossard (eds) Phosphorus in Action: Biological Processes in Soil Phosphorus Cycling. Springer Berlin Heidelberg, Berlin, Heidelberg.

Nash DM, Haygarth PM, Turner BL, Condron LM, McDowell RW, Richardson AE, Watkins M, Heaven MW (2014) Using organic phosphorus to sustain pasture productivity: A perspective. Geoderma 221: 11-19. doi: 10.1016/j.geoderma.2013.12.004.

Neal AL, Ahmad S, Gordon-Weeks R, Ton J (2012) Benzoxazinoids in root exudates of maize attract Pseudomonas putida to the rhizosphere. PloS One 7: e35498. doi: 10.1371/journal.pone.0035498.

Neal AL, Rossman M, Brearley C, Akkari E, Guyomar C, Clark IM, Allen E, Hirsch PR (2017) Land-use influences phosphatase gene microdiversity. Environ. Microbiol. (in press doi:10.1111/14622920.13778)

Negassa W, Leinweber P (2009) How does the Hedley sequential phosphorus fractionation reflect impacts of land use and management on soil phosphorus: A review. J Plant Nutr Soil Sci-Z Pflanzenernahr Bodenkd 172: 305-325. doi: 10.1002/jpln.200800223.

Nisticò R, Evon P, Labonne L, Vaca-Medina G, Montoneri E, Francavilla M, Vaca-Garcia C, Magnacca G, Franzoso F, Negre M (2016) Extruded Poly(ethylene-co-vinyl alcohol) Composite Films Containing Biopolymers Isolated from Municipal Biowaste. ChemistrySelect 1: 2354-2365. doi: 10.1002/slct.201600335.

Plassard C, Louche J, Ali MA, Duchemin M, Legname E, Cloutier-Hurteau B (2011) Diversity in phosphorus mobilisation and uptake in ectomycorrhizal fungi. Ann Forest Sci 68: 33-43. doi: 10.1007/s13595-0100005-7. 
Powers SM, Bruulsema TW, Burt TP, Chan NI, Elser JJ, Haygarth PM, Howden NJK, Jarvie HP, Lyu Y, Peterson HM, Sharpley AN, Shen J, Worrall F, Zhang F (2016) Long-term accumulation and transport of anthropogenic phosphorus in three river basins. Nature Geosci 9: 353-356. doi: 10.1038/ngeo2693

Ragot SA, Kertesz MA, Bünemann EK (2015) phoD Alkaline Phosphatase Gene Diversity in Soil. Appl Environ Microbiol 81: 7281-7289. doi: 10.1128/aem.01823-15.

Ragot SA, Kertesz MA, Mészáros É, Frossard E, Bünemann EK. (2016) Soil phoD and phoX alkaline phosphatase gene diversity responds to multiple environmental factors. FEMS microbiology ecology. 93:fiw212.

Redfield AC (1958) The biological control of chemical factors in the environment American Scientist 46: 230A221.

Richardson AE, Hocking PJ, Simpson RJ, George TS (2009) Plant mechanisms to optimise access to soil phosphorus. Crop Past. Sci. 60: 124-143.

Richardson AE, Lynch JP, Ryan PR, Delhaize E, Smith FA, Smith SE, Harvey PR, Ryan MH, Veneklaas EJ, Lambers H, Oberson A, Culvenor RA, Simpson RJ (2011) Plant and microbial strategies to improve the phosphorus efficiency of agriculture. Plant Soil 349: 121-156. doi: 10.1007/s11104-011-0950-4.

Rosemarin A, Ekane N (2015) The governance gap surrounding phosphorus. Nutri Cycl Agroecosys: 1-15. doi: 10.1007/s10705-015-9747-9.

Rosling A, Midgley MG, Cheeke T, Urbina H, Fransson P, Phillips RP (2016) Phosphorus cycling in deciduous forest soil differs between stands dominated by ecto- and arbuscular mycorrhizal trees. New Phytol 209: 1184-1195. doi: 10.1111/nph.13720.

Runge-Metzger A (1995) Closing the cycle: obstacles to efficient P management for improved global food security. Scope-Scientific Committee on Problems of the Environment International Council of Scientific Unions 54: 27-42.

Santos-Beneit F (2015) The Pho regulon: a huge regulatory network in bacteria. Frontiers in Microbiology 6. doi: 10.3389/fmicb.2015.00402.

Schneider KD, Cade-Menun BJ, Lynch DH, Voroney RP (2016) Soil Phosphorus Forms from Organic and Conventional Forage Fields. Soil Sci Soc Am J 80: 328-340. doi: 10.2136/sssaj2015.09.0340.

Sebastian M, Ammerman JW (2009) The alkaline phosphatase PhoX is more widely distributed in marine bacteria than the classical PhoA. ISME 3: 563-572. doi: 10.1038/ismej.2009.10. 
Secco D, Wang C, Shou H, Whelan J (2012) Phosphate homeostasis in the yeast Saccharomyces cerevisiae, the key role of the SPX domain-containing proteins. FEBS letters 586: 289-295. doi: 10.1016/j.febslet.2012.01.036.

Sharma R, Bella RW, Wong MTF (2017) Dissolved reactive phosphorus played a limited role in phosphorus transport via runoff, throughflow and leaching on contrasting cropping soils from southwest Australia. Sci. Tot. Env. 577: 33-44.

Sharpley AN, Bergström L, Aronsson H, Bechmann M, Bolster CH, Börling K, Djodjic F, Jarvie HP, Schoumans OF, Stamm C, Tonderski KS, Ulén B, Uusitalo R, Withers PJA (2015) Future agriculture with minimized phosphorus losses to waters: Research needs and direction. AMBIO 44: 163-179. doi: $10.1007 / s 13280-014-0612-x$.

Slazak A, Freese D, da Silva Matos E, Hüttl RF (2010) Soil organic phosphorus fraction in pine-oak forest stands in Northeastern Germany. Geoderma 158: 156-162.

Spohn M, Kuzyakov Y (2013) Distribution of microbial- and root-derived phosphatase activities in the rhizosphere depending on P availability and C allocation - Coupling soil zymography with 14C imaging. Soil Biol Biochem 67: 106-113. doi: http://dx.doi.org/10.1016/j.soilbio.2013.08.015.

Stewart JWB, Tiessen H (1987) Dynamics of soil organic phosphorus. Biogeochem 4: 41-60. doi: $10.1007 / \mathrm{bf02187361.}$

Stutter MI, Shand CA, George TS, Blackwell MSA, Bol R, MacKay RL, Richardson AE, Condron LM, Turner BL, Haygarth PM (2012) Recovering Phosphorus from Soil: A Root Solution? Environ SciTechnol 46: 1977-1978. doi: 10.1021/es2044745.

Stutter MI, Shand CA, George TS, Blackwell MSA, Dixon L, Bol R, MacKay RL, Richardson AE, Condron LM, Haygarth PM (2015) Land use and soil factors affecting accumulation of phosphorus species in temperate soils. Geoderma 257-258: 29-39. doi: 10.1016/j.geoderma.2015.03.020.

Tamburini F, Pfahler V, von Sperber C, Frossard E, Bernasconi SM (2014) Oxygen Isotopes for Unraveling Phosphorus Transformations in the Soil-Plant System: A Review. Soil Sci Soc Am J 78: 38-46. doi: 10.2136/sssaj2013.05.0186dgs.

Tan H, Barret M, Mooij MJ, Rice O, Morrissey JP, Dobson A, Griffiths B, O’Gara F (2013) Long-term phosphorus fertilisation increased the diversity of the total bacterial community and the phoD phosphorus mineraliser group in pasture soils. Biol Fertil Soils 49: 661-672. doi: 10.1007/s00374-0120755-5. 
Tate KR, Salcedo I (1988) Phosphorus control of soil organic matter accumulation and cycling. Biogeochem 5: 99-107. doi: 10.1007/bf02180319.

Tipping E, Somerville CJ, Luster J (2016) The C:N:P:S stoichiometry of soil organic matter. Biogeochem 130: 117-131. doi: 10.1007/s10533-016-0247-z.

Tkacz A, Cheema J, Chandra G, Grant A, Poole PS (2015) Stability and succession of the rhizosphere microbiota depends upon plant type and soil composition. ISME J 9: 2349-2359. doi: 10.1038/ismej.2015.41.

Toor GS, Condron LM, Di HJ, Cameron KC, Cade-Menun BJ (2003) Characterization of organic phosphorus in leachate from a grassland soil. Soil Biol. Biochem. 35:1317-23.

Trouillefou CM, Le Cadre E, Cacciaguerra T, Cunin F, Plassard C, Belamie E (2015) Protected activity of a phytase immobilized in mesoporous silica with benefits to plant phosphorus nutrition. J Sol-Gel Sci Technol 74: 55-65. doi: 10.1007/s10971-014-3577-0.

Turner BL, Cade-Menun BJ, Condron LM, Newman S (2005) Extraction of soil organic phosphorus. Talanta 66: 294-306. doi: 10.1016/j.talanta.2004.11.012.

Turner BL, Cheesman AW, Condron LM, Reitzel K, Richardson AE (2015) Introduction to the special issue: Developments in soil organic phosphorus cycling in natural and agricultural ecosystems. Geoderma 257-258: 1-3. doi: http://dx.doi.org/10.1016/j.geoderma.2015.06.008.Turner BL, Frossard E, Baldwin DS, editors. (2005) Organic phosphorus in the environment. CABI Pub.pp 377-380.

Uusitalo R, Turtola E, Puustinen M, Paasonen-Kivekas M, Uusi-Kamppa J (2003) Contribution of particulate phosphorus to runoff phosphorus bioavailability. J Environ Qual 32: 2007-2016.

Vollmer-Sanders C, Allman A, Busdeker D, Moody LB, Stanley WG (2016) Building partnerships to scale up conservation: 4R Nutrient Stewardship Certification Program in the Lake Erie watershed. J Great Lakes Res. doi: http://dx.doi.org/10.1016/j.jglr.2016.09.004.

von Sperber C, Kries H, Tamburini F, Bernasconi SM, Frossard E (2014) The effect of phosphomonoesterases on the oxygen isotope composition of phosphate. Geochimica et Cosmochimica Acta 125: 519-527. doi: 10.1016/j.gca.2013.10.010.

Wieder WR, Grandy AS, Kallenbach CM, Taylor PG, Bonan GB (2015) Representing life in the Earth system with soil microbial functional traits in the MIMICS model. Geosci Model Dev 8: 1789-1808. doi: 10.5194/gmd-8-1789-2015. 
747 Withers PJA, Hartikainen H, Barberis E, Flynn NJ, Warren GP (2009) The effect of soil phosphorus on particulate phosphorus in land runoff. Euro J Soil Sci 60: 994-1004. doi: 10.1111/j.13652389.2009.01161.x.

750

Zaia FC, Gama-Rodrigues AC, Gama-Rodrigues EF, Moço MKS, Fontes AG, Machado RCR, Baligar VC (2012) Carbon, nitrogen, organic phosphorus, microbial biomass and $\mathrm{N}$ mineralization in soils under

752 cacao agroforestry systems in Bahia, Brazil. Agroforest Sys 86: 197-212. doi: 10.1007/s10457-0129550-4.

754

Zhou Z, Hartmann M (2012) Recent Progress in Biocatalysis with Enzymes Immobilized on Mesoporous Hosts. Topics Catalysis 55: 1081-1100. doi: 10.1007/s11244-012-9905-0.

756

Zimmerman AE, Martiny AC, Allison SD (2013) Microdiversity of extracellular enzyme genes among sequenced prokaryotic genomes. ISME 7: 1187-1199. doi: 10.1038/ismej.2012.176. 
Generic structure:
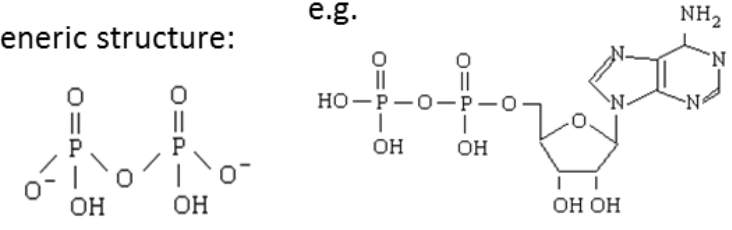

Adenosine diphosphate (ADP)

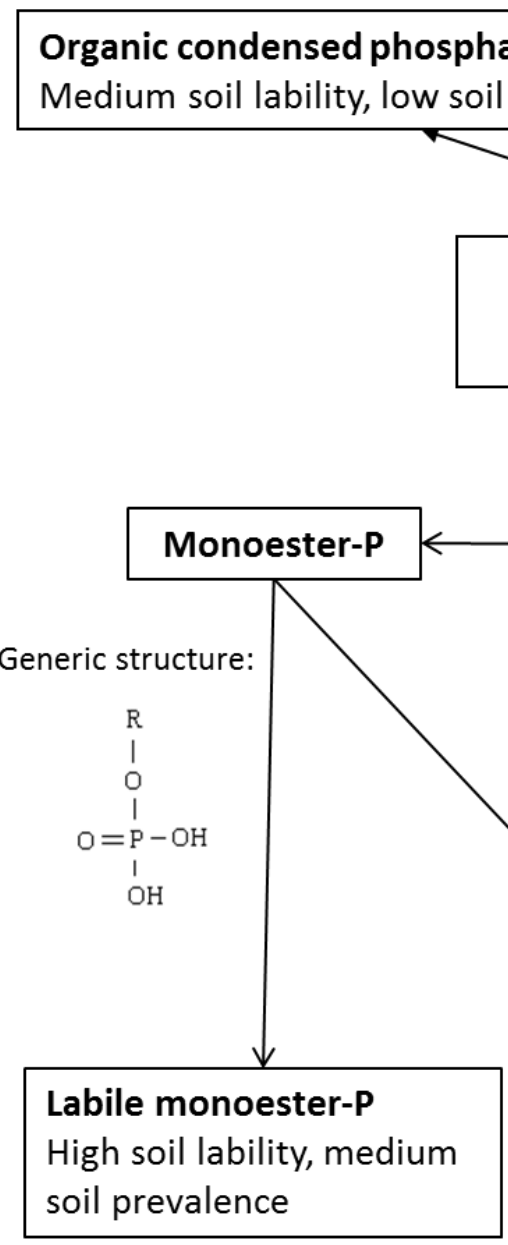

e.g.

FIGURE 1. Organic phosphorus forms with generic and example structures and information on the relative lability and prevalence in soil. (Adapted from Darch et al. (Darch et al. 2014))
Generic structure:

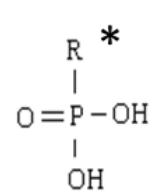

e.g.

$$
\underset{\text { 2-aminoethylphosphonic acid }}{\mathrm{HO}-\mathrm{P}}-\mathrm{CH}_{2}-\mathrm{CH}_{2}-\mathrm{NH}_{2}
$$

\section{Phosphonates (C-P bond)}

Low soil lability and prevalence

\section{Organic phosphorus compounds}
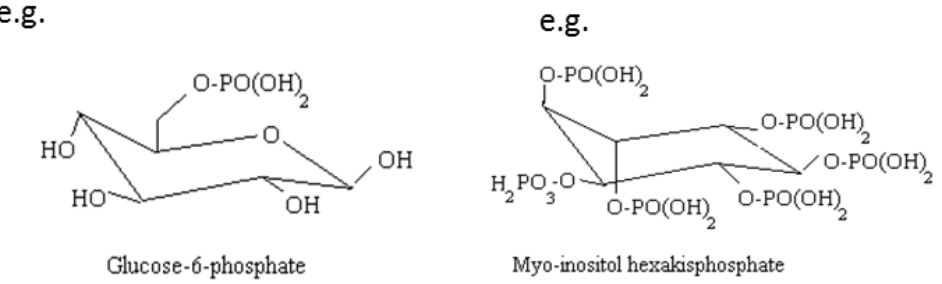

* The ' $\mathrm{R}$ ' in chemical formulae denotes an organic group

\section{High soil lability,} medium soil prevalence

\section{Inositol Phosphates} Low soil lability, high soil prevalence

Myo-inositol hexakisphosphate 
Table Legend

765

766 Table 1: Synthesis of expert opinions on the global issues associated with organic phosphorus, how the research

767 community can potentially contribute to solutions to such issues, and identification of opportunities for research

768 to allow this to happen.

769 


\begin{tabular}{|c|c|c|c|c|}
\hline $\begin{array}{l}\text { What are the global } \\
\text { issues associated with } \\
P_{0} \text { ? }\end{array}$ & $\begin{array}{l}\text { What are the } \\
\text { methodological } \\
\text { strengths and }\end{array}$ & $\begin{array}{c}\text { What are benefits of } \\
\text { understanding } \\
\text { dynamics of } P_{0} \text { ? }\end{array}$ & What are the priorities for $P_{0}$ research? & $\begin{array}{c}\text { Opportunities in } \\
\text { Po research }\end{array}$ \\
\hline $\begin{array}{l}\text { Food Security and } \\
\text { agricultural } \\
\text { sustainability } \\
\mathrm{P}_{\mathrm{o}} \text { has a role as a } \\
\text { source of } \mathrm{P} \text { for } \\
\text { aoricultural crons }\end{array}$ & $\begin{array}{l}\text { Strengths } \\
\text { Strong collection of }\end{array}$ & $\begin{array}{l}\text { Management of plant } \mathrm{P} \\
\text { nutrition } \\
\text { Assessment of soil } \mathrm{P} \\
\text { availability }\end{array}$ & $\begin{array}{l}\text { - } \quad \text { Use existing datasets more effectively } \\
\text { - } \quad \text { Avoid repeating experiments by being aware of } \\
\text { past research } \\
\text { - } \quad \text { Better access to shared facilities } \\
\text { - } \quad \text { Training programmes in } \mathrm{P}_{\mathrm{o}} \text { related techniques } \\
\text { and concepts } \\
\text { - } \quad \text { Interdisciplinary and long term research }\end{array}$ & $\begin{array}{l}\text { General } \\
\text { advances in the } \\
\text { research model }\end{array}$ \\
\hline $\begin{array}{l}\text { Nutrient cycling in } \\
\text { natural ecosystems } \\
\mathrm{P}_{\mathrm{o}} \text { buffers ecosystem } \\
\text { function with effects } \\
\text { on ecosystem } \\
\text { resilience and }\end{array}$ & $\begin{array}{l}\text { Wide range of } \\
\text { techniques } \\
\text { Capacity for multi- } \\
\text { disciplinarity }\end{array}$ & $\begin{array}{l}\text { Understanding biological } \\
\text { system function } \\
\text { Input into climate and } \\
\text { biogeochemical models } \\
\text { Potential to close the P }\end{array}$ & $\begin{array}{ll}\text { - } & \text { Link operationally-defined pools with } \\
\text { biological processes } \\
\text { - } & \text { Some standardisation of protocols } \\
\text { - } & \text { Development of in situ, non-destructive } \\
\text { techniques for } \mathrm{P}_{\mathrm{o}} \\
\text { - }\end{array}$ & $\begin{array}{l}\text { Opportunities in } \\
\text { organic } \\
\text { phosphorus } \\
\text { analytical } \\
\text { methodologies }\end{array}$ \\
\hline $\begin{array}{l}\text { biodiversity } \\
\text { Renewable resources } \\
\text { Use of wastes } \\
\text { containing } \mathrm{P}_{\mathrm{o}} \text { as } \\
\text { fertilisers to close the } \\
\text { loop }\end{array}$ & $\begin{array}{l}\text { Strong international } \\
\text { networks } \\
\text { Potential for } \\
\text { commercialisation of } \\
\text { techniques }\end{array}$ & $\begin{array}{l}\text { cycle } \\
\text { Manage ecosystem } \\
\text { services and resilience } \\
\text { Understand the role of } \\
\text { soil biology - fungal vs }\end{array}$ & 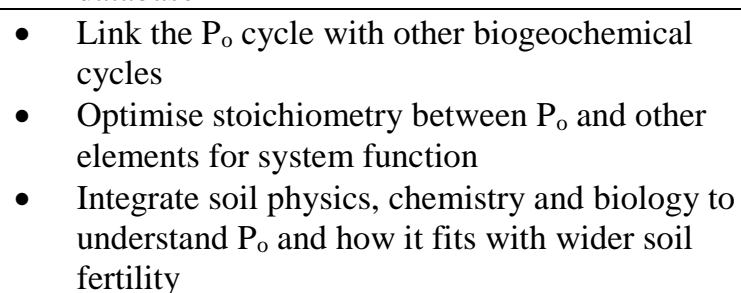 & $\begin{array}{l}\text { Opportunities } \\
\text { from } \\
\text { understanding } \\
\text { stoichiometry - } \\
\text { interactions with } \\
\text { other element } \\
\text { cycles }\end{array}$ \\
\hline $\begin{array}{l}\text { C storage in soils } \\
\text { Utilisation of soil } \mathrm{P}_{\mathrm{o}} \\
\text { may be counter to our } \\
\text { need to store } \mathrm{C} \text { in } \\
\text { organic matter } \\
\text { Environmental } \\
\text { pollution }\end{array}$ & $\begin{array}{l}\text { Range of field based } \\
\text { applications } \\
\text { Weaknesses } \\
\text { 'Snap-shot' rather } \\
\text { than dynamic }\end{array}$ & $\begin{array}{l}\text { bacterial dominated } \\
\text { systems } \\
\text { Assess stability of P } \\
\text { forms in soil }\end{array}$ & 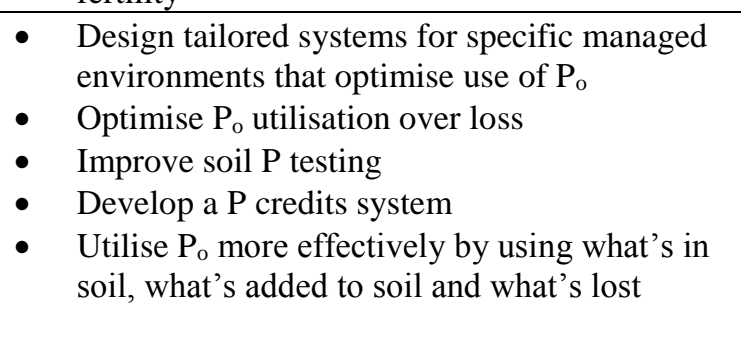 & $\begin{array}{l}\text { Opportunities } \\
\text { from } \\
\text { understanding } \\
\text { interactions with } \\
\text { land } \\
\text { management }\end{array}$ \\
\hline
\end{tabular}




\begin{tabular}{|c|c|c|c|c|}
\hline $\begin{array}{l}\text { Need to manage the } \\
\text { balance of food } \\
\text { security vs } \\
\text { environmental P } \\
\text { pollution } \\
\text { Environmental } \\
\text { change } \\
\text { Warmer temperatures } \\
\text { will shift the } \\
\text { biogeochemical cycle } \\
\text { of } \mathrm{P}_{\mathrm{o}} \\
\text { Biogeochemical } \\
\text { cycling from global to } \\
\text { cellular scales } \\
\mathrm{P}_{\mathrm{o}} \text { compounds are vital } \\
\text { for cell function and } \\
\text { are moved globally as } \\
\text { part of biogeochemical } \\
\text { cycles and in the food } \\
\text { chain } \\
\text { Geopolitical stability } \\
\mathrm{P}_{\mathrm{o}} \text { as an alternative to } \\
\text { mined P resources }\end{array}$ & $\begin{array}{l}\text { techniques } \\
\text { Operational } \\
\text { methodologies lack } \\
\text { biological relevance } \\
\text { Lack of } \\
\text { standardisation and } \\
\text { quality control } \\
\text { Methodological } \\
\text { limitations (matrix } \\
\text { issues) } \\
\text { Loss of } \\
\text { training/education in } \\
\text { soil science } \\
\text { Lack of replication } \\
\text { and appropriate } \\
\text { statistical approaches } \\
\text { Limited access to } \\
\text { advanced techniques } \\
\text { for all }\end{array}$ & $\begin{array}{l}\text { Identify mechanisms } \\
\text { from natural systems that } \\
\text { can be applied in } \\
\text { managed systems } \\
\text { Separate plant and } \\
\text { microbial contributions } \\
\text { to soil functions } \\
\text { Develop indicators for } \\
\text { tipping points in } \\
\text { ecosystem function - } \\
\text { identify conditions of } \\
\text { resistance, resilience and } \\
\text { "points of no return" } \\
\text { Allow scaling up in time } \\
\text { and space through input } \\
\text { to models } \\
\text { Extend our } \\
\text { understanding of global } \\
\text { nutrient dynamics } \\
\text { beyond what can be } \\
\text { ascertained empirically }\end{array}$ & 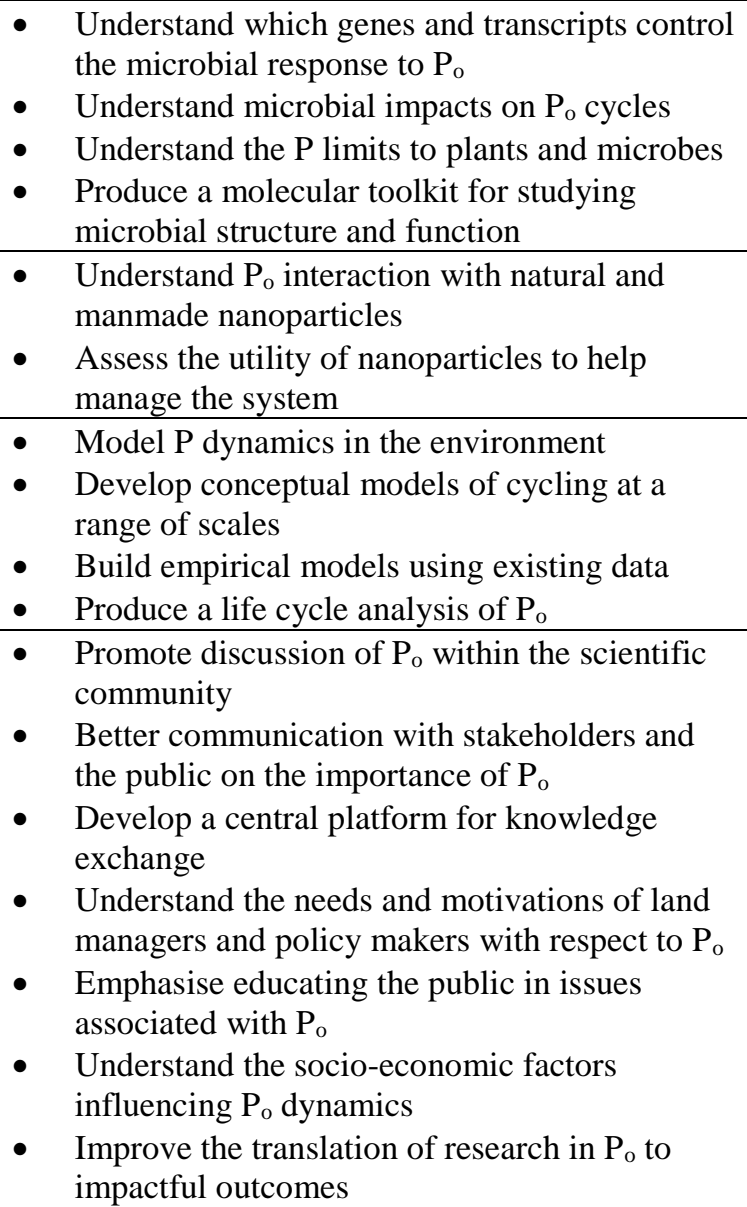 & $\begin{array}{l}\text { Opportunities } \\
\text { from } \\
\text { understanding } \\
\text { Microbial Po: } \\
\text { Function and } \\
\text { dynamics } \\
\text { Opportunities } \\
\text { from interactions } \\
\text { with } \\
\text { nanoparticles } \\
\text { Opportunities to } \\
\text { use modelling of } \\
\text { Po in soil and } \\
\text { ecosystems }\end{array}$ \\
\hline
\end{tabular}

